NBER WORKING PAPER SERIES

\title{
OWNERSHIP AND CONTROL IN OUTSOURCING TO CHINA: ESTIMATING THE PROPERTY-RIGHTS THEORY OF THE FIRM
}

\author{
Robert C. Feenstra \\ Gordon H. Hanson \\ Working Paper 10198 \\ http://www.nber.org/papers/w10198
}

\section{NATIONAL BUREAU OF ECONOMIC RESEARCH 1050 Massachusetts Avenue Cambridge, MA 02138}

December 2003

We thank Barry Naughton and seminar participants at Brown University, Claremont Graduate University, Columbia University, Harvard University, the NBER, Northwestern University, Princeton University, Stanford University, UC Irvine, UCLA, UCSD, the University of Michigan, and the University of Wisconsin for helpful comments. Jeffrey Lin and Songhua Lin provided excellent research assistance. The views expressed herein are those of the authors and not necessarily those of the National Bureau of Economic Research.

(C)2003 by Robert C. Feenstra and Gordon H. Hanson. All rights reserved. Short sections of text, not to exceed two paragraphs, may be quoted without explicit permission provided that full credit, including $\mathbb{C}$ notice, is given to the source. 
Ownership and Control in Outsourcing to China:

Estimating the Property-Rights Theory of the Firm

Robert C. Feenstra and Gordon H. Hanson

NBER Working Paper No. 10198

December 2003

JEL No. F14, L23

\begin{abstract}
In this paper, we develop a simple model of international outsourcing and apply it to processing trade in China. We observe China's processing exports broken down by who owns the plant and by who controls the inputs the plant processes. Multinational firms engaged in export processing in China tend to split factory ownership and input control with managers in China: the most common outcome is to have foreign factory ownership but Chinese control over input purchases. To account for this organizational arrangement, we appeal to a property-rights model of the firm. Multinational firms and the Chinese factory managers with whom they contract divide the surplus associated with export processing by Nash bargaining. Investments in input search, production, and marketing are partially relationship specific. In our benchmarks estimates, this relationship specificity is lowest in southern coastal provinces, where export markets are thickest, and highest in interior and northern provinces. The probability contracts are enforced has a similar pattern and is the lowest along the southern coast and the highest in the north.
\end{abstract}

\author{
Robert C. Feenstra \\ Department of Economics \\ University of California \\ Davis, CA 95616 \\ and NBER \\ rcfeenstra@ucdavis.edu \\ Gordon H. Hanson \\ IR/PS \\ University of California, San Diego \\ 9500 Gilman Drive \\ La Jolla, CA 92093 \\ and NBER \\ gohanson@ucsd.edu
}




\section{Introduction}

Global production is a common feature of the modern firm. Businesses as diverse as Mattel, which makes plastic dolls, Dell, which sells personal computers, and Intel, which makes semiconductors, operate supply chains that span multiple countries. Typically, multinational firms produce components in one location, process components into final goods in another location, and manage these operations from headquarters in yet another location. While trade theory has used general-equilibrium models to examine location decisions by multinational firms, ${ }^{1}$ the literature has tended to abstract away from how multinationals set firm boundaries within global supply chains. Until recently, trade theory has not sought to explain why Intel would use wholly-owned subsidiaries in China and Costa Rica to assemble its microchips, while Dell and Mattel subcontract production to outside firms in many countries. Nor has it tried to account for why Dell would control who buys what from whom along its PC supply chain, while Mattel grants the suppliers that make its dolls latitude in finding sources for materials.

In a new body of work, trade theorists have started to bring modern theories of the firm into models of international trade. ${ }^{2}$ Grossman and Helpman (2002a,b) and Antras (2001) use the property-rights theory of Grossman and Hart (1986) and Hart and Moore (1990) to model global outsourcing and intra-firm trade. Grossman and Helpman (2002c) apply the incentive-systems framework of Holmstrom and Milgrom (1994) to model managerial compensation in global production, and Marin and Verdier (2001, 2003) and Puga and Trefler (2002) extend the Aghion and Tirole (1997) theory of delegating authority to general equilibrium.

In this paper, we build a simple model of international outsourcing and apply this model to China. We consider a multinational firm that has decided to setup an export processing plant

\footnotetext{
${ }^{1}$ See Markusen (2002) and Markusen and Maskus (2003) for surveys.

${ }^{2}$ For early work on firm boundaries in international trade, see Ethier and Markusen (1996) and McLaren (2000).
} 
in a low-wage country. In this arrangement, the firm sends intermediate inputs to a processing factory, which converts the inputs into finished goods and then exports the final output. The decisions facing the multinational include who should own the processing factory and who should control input-purchase decisions the factory makes. Following recent trade literature, we use the Grossman-Hart-Moore property-rights (PR) theory as the basis for our model. In this framework, parties use control rights over productive assets to ameliorate hold-up problems created by incomplete contracts. We also build simple contracting costs into the model, in the spirit of the Holmstrom-Milgrom incentive-systems (IS) framework.

The application to China is motivated by the importance of export processing to global trade and by the availability of detailed trade data on China. As described in section 2, we observe China's processing exports broken down by who owns the plant and by who controls the inputs the plant processes. Since the early 1980s, China has permitted foreign ownership of export processing plants. It stipulates that all processing plants (whether Chinese or foreign owned) operate according to one of two regimes: a pure-assembly regime, in which a foreign buyer supplies a plant in China with inputs and hires the plant to process them into finished goods, all the while retaining ownership over the inputs; and an import-and-assembly regime, in which a plant in China imports inputs of its own accord, processes them, and sells the processed goods to a foreign buyer. This level of contractual detail is rarely observed in international trade.

In our model of export processing, presented in section 3, parties have the option of writing a legal contract to govern trade, where with some probability the contract will be not be verifiable and parties will be forced to divide gains from trade by Nash bargaining. The threatpoint payoffs associated with bargaining do not fully compensate parties for their investments in human capital and depend, in standard fashion, on who has the relevant control rights (i.e., 
ownership of the factory or control over input decisions). Whether factory ownership and input control should be given to the same or to different parties depends on parameters of the model, including the specificity of human-capital investments in the project, value-added in the processing factory, and the Nash bargaining weights. When human-capital specificity is low, value added is high, or the bargaining weight of the multinational is high, the multinational can ameliorate the hold-up problem by transferring control of input purchases to the manager. This will improve the manager's incentive to make investments specific to the multinational even when she does not own the factory, so that ownership and control are given to different parties. However, when human-capital specificity is high, value added is low, or the multinational's bargaining weight is low, then ownership and control should be given to the same party.

On the basis of the model, we develop a stochastic specification for organizational decisions in export processing, which is presented in section 4. Previewing the empirical results in section 5, we find that multinational firms engaged in export processing in China tend to split factory ownership and input control with factory managers in China: the most common outcome is to have foreign factory ownership but Chinese control over input purchases. This is consistent with moderate or low human-capital specificity, which our estimates of these parameters confirm. In our benchmarks estimates, the specificity of human-capital investments is estimated at $28-51 \%$ in interior and northern provinces but only about $22 \%$ in southern coastal provinces, where export production is concentrated. Thus, the specificity of investments appears to be lowest where export markets are thickest. The probability of legal enforcement of contracts has a similar pattern and is the lowest in the southern coastal provinces, and the highest in the north. Our preferred estimate of the Nash bargaining weight for multinational firms is 0.7 , but the confidence interval includes the value of 0.5 , which corresponds to simple Nash bargaining. 
Our findings are relevant to several bodies of literature. While incomplete contracts are a staple feature of recent trade models, there is little empirical work on whether contracting costs matter for international trade. ${ }^{3}$ We estimate sources of contractual incompleteness in global production. A second body of literature to which our work relates is empirical work on modern theories of the firm. Despite intense theoretical interest in the PR and other models, few papers have tested them. ${ }^{4}$ A notable exception is Baker and Hubbard (2000a,b) who examine contractual arrangements in U.S. trucking. They exploit the introduction of on-board computers in trucks, which changed the costs of monitoring truck drivers. They find evidence consistent with the PR and IS models. Our work, which exploits the interaction between choices over ownership and input-purchase regimes, is similar in spirit to theirs. Our work extends the literature by estimating contracting costs in a developing-country context, where contractual incompleteness is often assumed to be severe but is rarely estimated empirically.

\section{Export Processing in China}

Export processing plays a major role in China's foreign trade. Table 1 shows that over the years 1997-2002, which spans our sample period, processing exports accounted for 55.6\% of China's total exports. Export processing in China is broadly similar to that in other countries. It involves a firm in China importing intermediate inputs, processing the inputs, and then exporting the finished goods. The inputs are imported duty-free (as are any investment goods used in export processing) as long as these goods are only used to produce exports. China has two regulatory regimes for export processing.

\footnotetext{
${ }^{3}$ See Rauch (1999) and Rauch and Casella (2000) on networks and information costs in international trade.

${ }^{4}$ For surveys of the theoretical literature, see Hart (1995) and Tirole (1999) and for surveys of the empirical literature, see Baker and Hubbard (2001) and Whinston (2001).
} 
The Pure-Assembly Regime. ${ }^{5}$ In this arrangement, a foreign firm supplies a factory in China with materials from abroad (Naughton, 1996). The factory in China, whose role is relatively passive, receives orders from and delivers processed goods to the foreign client, who then sells the goods outside China. While the factory takes possession of the imported materials during processing, the foreign firm retains ownership over them. The foreign firm pays the factory in China a fee for its processing services. To obtain clearance from Chinese customs to import materials and to export processed goods, the terms of the transaction between the Chinese factory and the foreign firm must be stipulated in a written contract and presented in advance to Chinese customs officials for approval. ${ }^{6}$ Legally, the processing factory may use imported materials for the sole purpose of meeting its obligations to the foreign client.

The Import-and-Assembly Regime. In this arrangement, the processing factory in China plays a more active role. Table 1 shows that this regime is the more common form of export processing, accounting for 70.7\% of processing exports over the 1997-2002 period. The factory imports materials of its own accord and takes ownership of these materials during processing. It may broker deals to process goods for multiple foreign firms (World Bank, 1994). Thus, the factory in China controls both the import of inputs and the export of processed goods (though usually not the marketing and sale of the good to end users). Legally, Chinese customs treats processing plants under this regime as bonded warehouses - facilities that are permitted to import inputs duty free under the proviso that they export all output. Bonded goods cannot be transferred to another party without the approval of Chinese customs. To become a bonded

\footnotetext{
${ }^{5}$ In Chinese trade statistics, the pure-assembly arrangement is called "processing and assembling" or "processing with supplied materials," and the import-and-assembly arrangement is called "processing with imported materials."

${ }^{6}$ The contract must specify the materials (and any equipment) to be imported, the processing activities to be performed, the fees to be paid, and the ports of entry and exit, among other items. See "Regulations Concerning Customs Supervision and Control over the Inward Processing and Assembling Operation (Amended)," Customs General Administration, October 5, 1990, http://www.moftec.gov.cn.
} 
warehouse, a plant must apply to the Chinese government and have warehouse facilities and accounting personnel that meet government standards. ${ }^{7}$ Under either regime, exporters are required to submit monthly reports on the status of their contracts and to verify that the contract has been completed within a month of having exported the finished goods.

There are several important distinctions between the two processing regimes. One relates to the responsibilities of the factory manager in China. Under pure-assembly, the manager appears to play a small role in searching for inputs or in other activities that precede input processing. Under import-and assembly, the factory manager has greater responsibility. A second distinction has to do with to controls rights over imported materials. Under pureassembly, the foreign buyer of the processed goods owns the materials used in processing. Without this buyer's consent, the factory in China cannot legally use the imported materials to process goods for another client. Under import-and-assembly, in contrast, the processing factory owns the imported materials. It may use them to produce for the foreign buyer of its choice, so long as the goods are exported. A third distinction between the two regimes is that they are subject to different approval processes and regulations. In particular, import-and-assembly factories are required to make greater investments in inventory storage and management. This suggests that a processing plant cannot costlessly or quickly change from one regime to another.

Processing factories may be owned by either Chinese or foreign interests. Foreigninvested enterprises (FIEs) play a major role in China's trade. Table 1 shows that over the period 1997-2002 FIEs accounted for $62.8 \%$ of China's processing exports. The Chinese government recognizes two categories of FIEs, wholly foreign-owned enterprises and equity joint ventures in which a foreign interest has at least a $25 \%$ ownership stake. One issue is whether a $25 \%$

\footnotetext{
${ }^{7}$ See "Measures on the Administration of the Customs of the People's Republic of China for Bonded Warehouse Factory Engaged in Processing Trade," Customs General Administration, April 6, 1988, http://www.moftec.gov.cn.
} 
ownership share gives a foreign party effective control over a processing factory. Standard definitions of whether an enterprise is foreign controlled set a lower ownership threshold, such as $10 \%$ in the case of the U.S. government. Following this precedent, we treat as foreign controlled both wholly owned factories and equity joint ventures. ${ }^{8}$

Export processing began to take off in China in the late 1980s. The pioneers in the sector included Hong Kong trading companies that set up processing plants across the border in Guangdong Province and used Hong Kong as a base from which to manage their operations (Sung, 1991). Hong Kong continues to mediate a large fraction of China's processing trade. Table 1 shows that over the sample period, $45.9 \%$ of China's processing exports were reexported through Hong Kong. Hong Kong traders provide a range of intermediation services, including finding foreign buyers, sorting and grading goods according to quality, labeling and packaging, and coordinating processing in China with processing in other countries (Naughton, 1997; Feenstra and Hanson, 2002). We shall examine whether processing exports re-exported through Hong Kong differ systematically from those shipped directly to destination markets.

\section{The Model}

We begin by describing the problem faced by a foreign firm wanting to locate export processing operations in China. The parties choose who should own the factory used in production and who should control the purchase of inputs processed by this factory. Our model follows closely the PR approach of Grossman and Hart (1986) and Hart and Moore (1990).

Consider a foreign firm, denoted by $\mathrm{f}$, transacting with a factory manager in China, denoted by g. The project requires the parties to purchase one unit of an input, to use a factory to

\footnotetext{
${ }^{8}$ The government also recognizes cooperative joint ventures as a mode of inward foreign investment (Sung, 1998). These are often non-equity arrangements between a foreign firm and a domestic partner that account for a small fraction of exports. Since these arrangements may not involve foreign investment, we exclude them from our definition of foreign-owned plants. Counting them as foreign-owned plants does not affect the results.
} 
process the input into one unit of a final product, and to market and to sell the final product.

Timing is as follows: In period 0 the parties choose who should own the factory and who should control input purchases; in period 1 the parties simultaneously make effort investments; and in period 2 the parties undertake input purchases, input processing, and final sales. All actions are observable to the two parties but not necessarily verifiable to a third party.

The efforts undertaken in period 1 are as follows: $\mathrm{e}_{1}=$ effort devoted to searching for a low-priced input, by either party $\mathrm{f}$ or $\mathrm{g}$; $\mathrm{e}_{2}=$ effort devoted to preparing the factory to produce, by the factor manager $\mathrm{g} ; \mathrm{e}_{3}=$ effort devoted to marketing the final good, by the foreign firm $\mathrm{f}$. The subscripts on these effort levels denote the stages of production rather than the timing, since all efforts are undertaken in period 1, before production and sale. The price of the input in period 2 is given by the linear function $\mathrm{P} \cdot\left(1-\mathrm{e}_{1}\right), \mathrm{P}>0,0 \leq \mathrm{e}_{1} \leq 1$, so that more search effort lowers the input price. The cost of input processing in period 2 is given by $A \cdot\left(1-e_{2}\right), A>0,0 \leq e_{2} \leq 1$, so that preparation effort lowers processing costs in period 2. Revenues from final sales in period 2 are given by $\mathrm{B} \cdot\left(1+\lambda \mathrm{e}_{2}+\mathrm{e}_{3}\right)$, where $0<\lambda \leq 1,0 \leq \mathrm{e}_{3} \leq 1$ and $\mathrm{B}>(\mathrm{A}+\mathrm{P})>0$, so that more preparation and marketing effort raises sales revenue. Combined period 2 profits are then,

$$
\pi=\mathrm{B}\left(1+\lambda \mathrm{e}_{2}+\mathrm{e}_{3}\right)-\mathrm{A}\left(1-\mathrm{e}_{2}\right)-\mathrm{P}\left(1-\mathrm{e}_{1}\right)>0 .
$$

Notice that we have introduced an element of joint production between input processing and sales revenue, with effort $\mathrm{e}_{2}$ by the factory manager affecting both. It is perhaps obvious that effort by the manager can reduce factory costs. An example, taken from Grossman and Helpman (2002c), where such effort also affects final sales is when the project is "successful" (leading to positive sales) with some probability that is increasing in $\mathrm{e}_{2}$. Joint production means 
that it may be difficult to compensate the manager at the first-best level, reflecting the marginal contributions of her effort to both processing costs and final sales.

The period 1 effort investments, $\mathrm{e}_{\mathrm{i}}, \mathrm{i}=1,2,3$, impose a cost on the parties involved. The variable $\delta_{1} \in\{0,1\}$ indicates whether the foreign firm $\mathrm{f}\left(\delta_{1}=0\right)$ or the manager $\mathrm{g}\left(\delta_{1}=1\right)$

expends search effort $\mathrm{e}_{1}$. We refer to this indicator variable as control over input purchases.

The costs to the foreign firm are given by $C_{f}\left[\left(1-\delta_{2}\right) e_{1}, e_{3}\right]=\frac{\gamma_{f}}{2}\left[\left(1-\delta_{1}\right) e_{1}^{2}+e_{3}^{2}\right]$, and the costs to the manager are given by $\mathrm{C}_{\mathrm{g}}\left(\delta_{1} \mathrm{e}_{1}, \mathrm{e}_{2}\right)=\frac{\gamma_{\mathrm{g}}}{2}\left(\delta_{1} \mathrm{e}_{1}^{2}+\mathrm{e}_{2}^{2}\right)$, where $\gamma_{\mathrm{f}}$ and $\gamma_{\mathrm{g}}$ are the disutility of effort for each party. The total surplus from the project is then,

$$
\mathrm{W}=\pi-\mathrm{C}_{\mathrm{h}}\left[\left(1-\delta_{1}\right) \mathrm{e}_{1}, \mathrm{e}_{3}\right]-\mathrm{C}_{\mathrm{f}}\left(\delta_{1} \mathrm{e}_{1}, \mathrm{e}_{2}\right),
$$

where first-best effort levels are $\mathrm{e}_{1}^{*}=\max \left\{\mathrm{P} / \gamma_{\mathrm{f}}, \mathrm{P} / \gamma_{\mathrm{g}}\right\}, \mathrm{e}_{2}^{*}=(\lambda \mathrm{B}+\mathrm{A}) / \gamma_{\mathrm{g}}$, and $\mathrm{e}_{3}^{*}=\mathrm{B} / \gamma_{\mathrm{f}}$.

In addition to input control, $\delta_{1}$, we introduce the ownership variable $\delta_{2} \in\{0,1\}$ to indicate whether the foreign firm $\mathrm{f}\left(\delta_{2}=0\right)$ or whether the Chinese manager $\mathrm{g}\left(\delta_{2}=1\right)$ owns the processing factory. While this indicator variable does not appear in the profits (1) or surplus (2), ownership of the factory certainly affects the effort levels of $\mathrm{f}$ and $\mathrm{g}$, as will be made clear below. With the effort levels depending on $\delta_{1}$ and $\delta_{2}$, the surplus in (2) also depends on these, which we write as $\mathrm{W}\left(\delta_{1}, \delta_{2}\right)$. The goal of our analysis is to see how $\mathrm{W}$ varies with $\delta_{1}$ and $\delta_{2}$. If $\mathrm{W}(0,0)+$ $\mathrm{W}(1,1)>\mathrm{W}(0,1)+\mathrm{W}(1,0)$ then $\mathrm{W}$ is strictly supermodular, so the highest values for $\mathrm{W}$ are obtained when $\delta_{1}$ and $\delta_{2}$ take on the same values and it is optimal for the same party to control the inputs and to own the factory. Conversely, when $\mathrm{W}(0,0)+\mathrm{W}(1,1)<\mathrm{W}(0,1)+\mathrm{W}(1,0)$ then 
$\mathrm{W}$ is strictly submodular, so it is optimal for $\delta_{1}$ and $\delta_{2}$ to take on different values, meaning that one party controls input purchases and the other owns the factory. As we shall see, our application of the PR model can lead to either outcome, depending on parameter values.

\subsection{Incomplete Contracting}

Essential to modern theories of the firm is that idea that contracts are imperfect or incomplete, so that the first-best effort levels cannot necessarily be obtained. In Grossman and Hart (1986), contracts are unenforceable, so there is Nash bargaining over ex post profits. In Holmstrom and Milgrom (1994), effort is observed with a random error, so wage compensation imperfectly rewards effort. We will combine elements of both approaches by assuming that with probability $(1-\phi)$ the parties' efforts can be verified, so that a first-best contract can be enforced, and with probability $\phi$ there is no verifiability and no contract, in which case the parties Nash bargain over profits. Thus, the parameter $\phi$ serves as a measure of contractual incompleteness.

We will allow for generalized Nash bargaining where the foreign firm has bargaining weight $\theta$ and the Chinese manager has weight $(1-\theta)$. The status quo or threat point payoffs for the two parties will be denoted by $\hat{\pi}_{\mathrm{f}}$ and $\hat{\pi}_{\mathrm{g}}$ (as specified below). Total ex post profits are given by (1), and the profits $\pi_{\mathrm{f}}$ and $\pi_{\mathrm{g}}$ earned by each party are then:

$$
\begin{array}{ll}
\text { Party f receives: } & \pi_{\mathrm{f}}=\hat{\pi}_{\mathrm{f}}+\theta\left(\pi-\hat{\pi}_{\mathrm{g}}-\hat{\pi}_{\mathrm{f}}\right)=\theta\left(\pi-\hat{\pi}_{\mathrm{g}}\right)+(1-\theta) \hat{\pi}_{\mathrm{f}} \\
\text { Party g receives: } & \pi_{\mathrm{g}}=\hat{\pi}_{\mathrm{g}}+(1-\theta)\left(\pi-\hat{\pi}_{\mathrm{f}}-\hat{\pi}_{\mathrm{g}}\right)=(1-\theta)\left(\pi-\hat{\pi}_{\mathrm{f}}\right)+\theta \hat{\pi}_{\mathrm{g}} .
\end{array}
$$

Given our assumption that Nash bargaining occurs with probability $\phi$, whereas first-best contracts occur with probability $(1-\phi)$, the expected payoffs to each party are then: 


$$
\begin{array}{ll}
\text { Party f payoff: } & \tilde{\pi}_{\mathrm{f}} \equiv \phi\left[\theta\left(\pi-\hat{\pi}_{\mathrm{g}}\right)+(1-\theta) \hat{\pi}_{\mathrm{f}}\right]+(1-\phi)\left[\mathrm{Be}_{3}+\left(1-\delta_{1}\right) \mathrm{Pe}_{1}\right] \\
\text { Party g payoff: } & \tilde{\pi}_{\mathrm{g}} \equiv \phi\left[(1-\theta)\left(\pi-\hat{\pi}_{\mathrm{f}}\right)+\theta \hat{\pi}_{\mathrm{g}}\right]+(1-\phi)\left[(\mathrm{A}+\lambda \mathrm{B}) \mathrm{e}_{2}+\delta_{1} \mathrm{Pe}_{1}\right] .
\end{array}
$$

Thus, each party will choose their effort levels to maximize the difference between these payoffs and the costs of supplying effort:

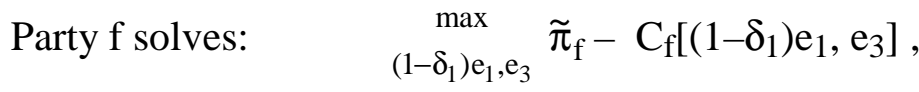

$$
\begin{aligned}
& \text { Party g solves: } \quad \max _{\delta_{1} \mathrm{e}_{1}, \mathrm{e}_{2}} \quad \tilde{\pi}_{\mathrm{g}}-\mathrm{C}_{\mathrm{g}}\left(\delta_{1} \mathrm{e}_{1}, \mathrm{e}_{2}\right),
\end{aligned}
$$

where the foreign firm $\mathrm{f}$ chooses $\mathrm{e}_{1}$ when $\delta_{1}=0$, while the manager $\mathrm{g}$ chooses $\mathrm{e}_{1}$ when $\delta_{1}=1$.

In order to solve these problems, we need to be more specific about the threat point payoffs received by each party. Our general assumption is that when Nash bargaining breaks down, the party not owning the factory can still make an arrangement with another factory. But in that case, the marginal product of his or her effort investment is reduced by $\psi$, so the payoffs are $(1-\psi)$ times their first-best level. Thus, $\psi$ measures the specificity of human-capital investments by either party in the project. For example, when the Chinese manager owns the factory $\left(\delta_{2}=1\right)$ and Nash bargaining breaks down, then the foreign firm will seek out another factory to work with. In that case, the threat-point payoff to the foreign firm is:

$$
\text { Party f threat-point when } \delta_{2}=1: \quad \hat{\pi}_{\mathrm{f}}=(1-\psi)\left[\mathrm{Be}_{3}+\left(1-\delta_{1}\right) \mathrm{Pe}_{1}\right]
$$

Meanwhile, the manager can still use the factory to process the input for another firm. We suppose that the transfer price received depends imperfectly on the marketing effort of the manager, $\hat{\mathrm{T}}=\mathrm{T}+\lambda(1-\psi) \mathrm{Be}_{2}$, but otherwise the manager has property rights over the residual profits of the firm. Her threat-point payoff is then: 
Party g threat-point when $\delta_{2}=1: \quad \hat{\pi}_{\mathrm{g}}=\hat{\mathrm{T}}-\mathrm{A}\left(1-\mathrm{e}_{2}\right)-\mathrm{P}\left(1-\delta_{1} \mathrm{e}_{1}\right)$.

Next, suppose that the foreign firm owns the factory $\left(\delta_{2}=0\right)$. In the case of disagreement over the ex post division of profits, the foreign firm retains ownership of the factory and hires another manager. There is no reason to expect that a new manager would have made prior effort investments, so in that event the profits of the foreign firm should be computed with $e_{2}=0$. Thus, the threat-point payoff of the foreign firm is:

Party $\mathrm{f}$ threat point when $\delta_{2}=0: \quad \hat{\pi}_{\mathrm{f}}=\mathrm{B}\left(1+\mathrm{e}_{3}\right)-\mathrm{A}-\mathrm{P}\left[1-\left(1-\delta_{1}\right) \mathrm{e}_{1}\right]$

The ex-manager must now find another factory to work with, and the amount that she earns from her effort investments is again reduced by $\psi$. We make the further assumption that when the manager does not own the factory her effort investments are valued more highly by another factory if she controls input purchases. In other words, a manager who is separated from a foreign firm is more productive in another firm if she brings with her the knowledge of how to purchase inputs; otherwise, she becomes part of the general labor pool, where her prior effort investments have little value. ${ }^{9}$ Normalizing the wage in the general labor pool at zero, then the threat point payoff to the manager when she does not own the factory is:

Party g threat point when $\delta_{2}=0: \quad \hat{\pi}_{\mathrm{g}}=\delta_{1}(1-\psi)\left[(\mathrm{A}+\lambda \mathrm{B}) \mathrm{e}_{2}+\mathrm{Pe}_{1}\right]$

\footnotetext{
${ }^{9}$ The key feature of this assumption is that giving the factory manager control over input purchases does more to improve her outside option (or, more precisely, to increase the sensitivity of her outside option to her effort investments) when she does not own the factory (and is in a weaker bargaining position) than when she does own the factory (and is in a stronger bargaining position). For simplicity, we normalize the return on the factory manager's investments in the threat point for case $\left(\delta_{1}, \delta_{2}\right)=(0,0)$ to zero, but this is not essential. We assume a similar asymmetry does not apply to the foreign firm (but all that is essential here is that any asymmetry between ownership regimes in how gaining control over input purchases affects outside options is larger for the factory manager than for the foreign firm). Since the foreign firm may transact with many managers, the impact of gaining control over input purchases on the firm's outside options is less likely to depend on whether it owns the factory.
} 
Substituting (7)-(10) into the objective functions (5) and (6), we can determine the optimal effort investments, as discussed in the next section.

\subsection{Solutions for Effort Investments}

Let us first consider the case where the foreign firm owns the factory, and also controls the input, so that $\left(\delta_{1}, \delta_{2}\right)=(0,0)$ in the upper-left cell of Table 2 . In the disagreement point the foreign firm receives the full marginal value from it's own effort investments, as shown in (9), since it owns the factory. It follows that the foreign firm's effort levels are at their first-best levels of $\mathrm{e}_{1}=\mathrm{P} / \gamma_{\mathrm{f}}$ and $\mathrm{e}_{3}=\mathrm{B} / \gamma_{\mathrm{f}}$. The manager, on the other hand, faces the threat-point payoffs in (10). When $\delta_{1}=0$, the manager's effort investments have no value in her outside option. Since the threat-point payoff has weight $\theta$ in (7), then $e_{2}=(1-\phi \theta)(A+\lambda B) / \gamma_{g}$, which is below its first-best level by the factor $\phi \theta$.

The case $\left(\delta_{1}, \delta_{2}\right)=(0,0)$ is particularly simple because the foreign firm retains ownership of the factory, and since it also makes the input decision, the manager has no property rights. To discuss other cases in Table 2, recall our assumption that a party loses $0 \leq \psi \leq 1$ times her marginal product if she works with another factory. In particular, consider the case $\left(\delta_{1}, \delta_{2}\right)=$

$(1,0)$ in the lower-left cell of Table 2 , so the foreign firm retains ownership of the factory but the factory manager now controls the input decision. In that case, if the manager goes to another factory then she loses $\psi$ times the marginal product of her effort investments. So the optimal investment towards processing the inputs is now $\mathrm{e}_{2}=(1-\phi \psi \theta)(\mathrm{A}+\lambda \mathrm{B}) / \gamma_{\mathrm{g}}$, which exceeds $\mathrm{e}_{2}=(1-\phi \theta)(\mathrm{A}+\lambda \mathrm{B}) / \gamma_{\mathrm{g}}$, as applies when the foreign firm has both factory ownership and input control. Thus, giving the manager control over input-search improves her incentive to 
make investments in processing the input. This is because the threat-point earnings from outside employment in (13) are conditional on having control over the input, $\delta_{1}=1$. However, her optimal effort in input-search is $\mathrm{e}_{1}=(1-\phi \psi \theta) \mathrm{P} / \gamma_{\mathrm{g}}$, which is less than the first-best.

In order to compute the levels of surplus $\mathrm{W}\left(\delta_{1}, \delta_{2}\right)$, we make use of the following result:

\section{$\underline{\text { Lemma }}$}

Suppose the efforts levels are $e_{1}=\left(1-\Delta_{1}\right) P / \gamma_{h}, h=f, g, e_{2}=\left[\left(1-\Delta_{2 a}\right) A+\left(1-\Delta_{2 b}\right) \lambda B\right] / \gamma_{g}$, and $\mathrm{e}_{3}=\left(1-\Delta_{3}\right) \mathrm{B} / \gamma_{\mathrm{f}}$. Then surplus is:

$$
\begin{aligned}
\mathrm{W}=(\mathrm{B} & -\mathrm{A}-\mathrm{P})+\frac{1}{2 \gamma_{\mathrm{h}}}\left(1-\Delta_{1}^{2}\right) \mathrm{P}^{2}+\frac{1}{2 \gamma_{\mathrm{f}}}\left(1-\Delta_{3}^{2}\right) \mathrm{B}^{2} \\
& +\frac{1}{2 \gamma_{\mathrm{g}}}\left[\left(1-\Delta_{2 \mathrm{a}}^{2}\right) \mathrm{A}^{2}+\left(1-\Delta_{2 \mathrm{a}} \Delta_{2 \mathrm{~b}}\right) 2 \lambda \mathrm{AB}+\left(1-\Delta_{2 \mathrm{~b}}^{2}\right) \lambda^{2} \mathrm{~B}^{2}\right] .
\end{aligned}
$$

This result follows by straightforward computation, and shows that the welfare loss is proportional to the square of the deviation of each effort level from its first-best value. Making use of (11) and the efforts shown in the first column of Table 2 , it is readily shown that $\mathrm{W}(0,0)$ cannot be ranked in general with $\mathrm{W}(1,0)$ : effort $\mathrm{e}_{1}$ is higher when the foreign firm controls input purchases, but effort $\mathrm{e}_{2}$ in processing the input is higher when the manager has input control.

Now consider the situation where the manager owns the processing factory $\left(\delta_{2}=1\right)$. The solutions for the effort investment are shown in the second column of Table 2 . When $\delta_{1}=0$, the foreign firm controls input purchases. As summarized in the upper-right cell of Table 2, all effort investments are below their first-best level. For the foreign firm, the marginal value of its investments are reduced by $\psi$ in its threat-point payoff, and since this occurs with probability $\phi$ and has weight $(1-\theta)$ in (3), its optimal efforts levels are $e_{1}=[1-\phi(1-\theta) \psi] \mathrm{P} / \gamma_{\mathrm{f}}$ and 
$\mathrm{e}_{3}=[1-\phi(1-\theta) \psi] \mathrm{B} / \gamma_{\mathrm{f}}$. The manager chooses $\mathrm{e}_{2}$, which has marginal value $\mathrm{A}+(1-\psi) \lambda \mathrm{B}$ in her threat-point payoff (8), compared with $(A+\lambda B)$ in profits $\pi$. Since the threat-point has weight $\phi \theta$ in (4), it follows that $e_{2}=[A+(1-\phi \theta \psi) \lambda B] / \gamma_{g}$, which is below the first-best level.

Suppose now that the manager controls input purchases, $\delta_{1}=1$. In that case, she receives full marginal value of $\mathrm{P}$ from search effort in both her threat-point payoff (8) and in total profits, $\pi$. It follows that her optimal search investment is at her own first-best level, $\mathrm{e}_{1}=\mathrm{P} / \gamma_{\mathrm{g}}$. The other efforts levels are unchanged from when the foreign firm controls the input decision. So the only difference between having one or the other party control the input decision is in their search efforts. With differing disutility of efforts, we cannot rank $\mathrm{W}(0,1)$ and $\mathrm{W}(1,1)$. If $\gamma_{\mathrm{f}}=\gamma_{\mathrm{g}}$, however, then it is clearly better to have the manager search for the input, since she undertakes this activity at her first-best level. So $\mathrm{W}(1,1)>\mathrm{W}(0,1)$ if $\gamma_{\mathrm{f}}=\gamma_{\mathrm{g}}$.

Using the effort levels in Table 2, the value of surplus in each case is computed as in (11). Then a convenient summary statistic is the modularity of the surplus function, computed by taking the sum of its values using the diagonal elements of Table 2, minus the sum of its value using the off-diagonal elements. We obtain:

$$
\begin{aligned}
\mathrm{W}(0,0) & +\mathrm{W}(1,1)-\mathrm{W}(0,1)-\mathrm{W}(1,0) \\
& =\mathrm{P}^{2}\left[\frac{\phi^{2}(1-\theta)^{2} \psi^{2}}{2 \gamma_{\mathrm{f}}}+\frac{\phi^{2} \theta^{2} \psi^{2}}{2 \gamma_{\mathrm{g}}}\right]-\frac{(\mathrm{A}+\lambda \mathrm{B})^{2} \phi^{2}\left(1-\psi^{2}\right) \theta^{2}}{2 \gamma_{\mathrm{g}}} .
\end{aligned}
$$

It is apparent that (12) can be positive or negative. In the former case the surplus function is strictly supermodular, meaning that the highest values tend to occur when $\delta_{1}=\delta_{2}$, so that factory ownership and input control go to the same party; in the latter case, the surplus function is 
strictly submodular so that the highest values tend to occur when $\delta_{1} \neq \delta_{2}$, so that ownership and control go to different parties. These results are summarized with:

\section{$\underline{\text { Proposition } 1}$}

The surplus function is strictly supermodular, so (12) is positive, if and only if,

$$
\left(\frac{\mathrm{A}+\lambda \mathrm{B}}{\mathrm{P}}\right)^{2}<\left(\frac{\psi^{2}}{1-\psi^{2}}\right)\left[1+\left(\frac{1-\theta}{\theta}\right)^{2}\left(\frac{\gamma_{\mathrm{g}}}{\gamma_{\mathrm{f}}}\right)\right] .
$$

Notice that the parameter $\phi$, indicating the degree of contractual incompleteness, does not appear in condition (13), so the modularity of the surplus function is independent of this parameter. This is because $\phi$ does not affect the relative bargaining power of the two parties. To interpret condition $(13)$, recall that $(A+\lambda B)$ is the marginal product of the manager's effort $\mathrm{e}_{2}$, while $e_{2}^{*}=(A+\lambda B) / \gamma_{g}$ is the first-best effort level, so that $(A+\lambda B)^{2} / \gamma_{g}$ would be the labor income received by the manager or value-added in the first-best. Similarly, if the manager controls the input decision, then $\mathrm{P}$ is the marginal product of her effort $\mathrm{e}_{1}$ and $\mathrm{e}_{1}^{*}=\mathrm{P} / \gamma_{\mathrm{g}}$ is the

first-best effort level, so $\mathrm{P}^{2} / \gamma_{\mathrm{g}}$ would be the labor income or value-added in the search activity. It follows that $[(\mathrm{A}+\lambda \mathrm{B}) / \mathrm{P}]^{2}$ is interpreted as the ratio of value-added in the factory relative to that in input search, or simply the value-added ratio, in the first-best.

Then (13) shows that if the value-added ratio is low, the parameter $\psi$ measuring the specificity of human-capital investments is high, or the foreign firm's Nash bargaining weight $\theta$ is low, then supermodularity of the surplus function is obtained. To explain this result, low value-added means that incentive problems are more acute in input search than in processing. Then from Table 2, the first-best levels of input search are obtained along the diagonal, when the 
same party has ownership of the factory and control over input sourcing. Relatedly, when $\psi$ is high (say, $\psi=1$ ) then the outside options are irrelevant and the disincentive for the manager to engage in processing effort $e_{2}$ is the same in all cells of Table $2: e_{2}=(A+\lambda B) / 2 \gamma_{g}$ when $\psi=1$, which is one-half of its first-best level. Then again, the relevant incentive problem occurs in input search rather than processing, which obtains its first-best along the diagonal, when ownership and control is given to the same party. In this case the surplus function is supermodular, as is also obtained when $\theta$ is sufficiently low. ${ }^{10}$

When value-added is high, however, or human-capital specificity is low, then surplus depends more on ameliorating the incentive problem in processing. In these cases, the manager's effort is improved by giving her better outside options. In particular, when the foreign firm owns the factory then the manager's outside options are improved by giving her control over the inputs. Because ownership and control are given to opposite parties, this means that the surplus function is submodular.

We can think of a low value of $\psi$, the measure of human-capital specificity, as indicating "thick labor markets" for the manager, since her outside options are improved. We might expect this to occur in coastal regions of China or in the country's special economic zones where export processing plants have agglomerated and where rules governing employment and firm creation are less restrictive. A lower value of $\psi$, or higher productivity in processing as measured by $(\mathrm{A}+\lambda \mathrm{B})$, both give more submodular values of the surplus function. This result follows directly from the measure of modularity in (12):

\footnotetext{
${ }^{10}$ When $\theta$ is low (say, $\theta=0$ ) and the factory manager has all the bargaining power, then she maximizes $\pi$ so all her effort decisions are at their first-best level. Likewise for the foreign firm provided that it owns the factory. When the manager owns the factory, however, then the foreign firm makes second-best effort choices on $\mathrm{e}_{3}$, and also on $\mathrm{e}_{1}$ when the foreign firm controls inputs. Thus, the worst outcome in this case is to have Chinese ownership and foreign control of inputs, leading to supermodular welfare.
} 


\section{Proposition 2}

Define $\mathrm{V} \equiv \mathrm{W}(0,0)+\mathrm{W}(1,1)-\mathrm{W}(0,1)-\mathrm{W}(1,0)$. Then:

$$
\frac{\partial \mathrm{V}}{\partial \mathrm{A}}<0, \frac{\partial \mathrm{V}}{\partial \mathrm{B}}<0, \frac{\partial \mathrm{V}}{\partial \lambda}<0, \text { and } \frac{\partial \mathrm{V}}{\partial \psi}>0
$$

Below, we apply this result by examining how processing exports vary across the four factoryownership and input-control regimes. More generally, the goals of our empirical analysis will be to assess the modularity of the surplus function and to estimate the model parameters.

\section{Stochastic Specification and Data}

\subsection{Multinomial Logit}

The modularity of the surplus function cannot be tested directly, because we do not observe the value of surplus from outsourcing activity; instead, we observe the processing exports accounted for by each ownership and control regime. To move from the value of surplus in (12) to the frequency of contractual regimes in our data, we adopt a simple stochastic specification. In particular, we suppose that ownership and control in our data are chosen to maximize $\mathrm{W}\left(\delta_{1}, \delta_{2}\right)$ plus an i.i.d. extreme value random error that varies across contractual types. ${ }^{11}$ Then it is well known (see, e.g., Train, 1986) that the probabilities of observing each contractual type take on the logit form:

$$
\operatorname{Pr}(i, j)=\frac{\exp [W(i, j)]}{\sum_{i, j=0,1} \exp [W(i, j)]}, \quad i, j \in\{0,1\}
$$

To measure the probabilities on the left of (15), we shall use the share of processing trade accounted for by each contractual type. Denoting these export shares by $\mathrm{S}(\mathrm{i}, \mathrm{j})$, our

\footnotetext{
${ }^{11}$ A stochastic specification of this type is suggested by Whinston (2001).
} 
measure of the modularity of the welfare function is then:

$$
\begin{aligned}
\mathrm{MOD} & \equiv[\ln \mathrm{S}(0,0)+\ln \mathrm{S}(1,1)-\ln \mathrm{S}(1,0)-\ln \mathrm{S}(0,1)] \\
& =[\mathrm{W}(0,0)+\mathrm{W}(1,1)-\mathrm{W}(1,0)-\mathrm{W}(0,1)]
\end{aligned}
$$

where the second line follows from replacing $\operatorname{Pr}(i, j)$ by $S(i, j)$ in $(17)$. We assess the modularity of the welfare function in Chinese export processing by calculating the expression for the sum of $\log$ export shares in the first line of equation (16). We then see how this expression varies across Chinese regions and trade policy regimes.

Turning to parametric techniques, if we observed individual export processing plants, then we could estimate (15) using standard multinomial logit techniques, in which the dependent variable would indicate which of the four factory-ownership/input-control regimes is chosen. Our data, while not at the factory level, are still highly disaggregated. For each of the four ownership/control regimes, we observe exports by year, Chinese city, type of economic zone, product, and destination market, yielding approximately 170,000 observations per year. For the vast majority of these year-city-zone-product-destination country cells, exports are positive in only one of the four input-country/ownership regimes. This makes it feasible to use multinomial logit to estimate the underlying parameters of the welfare function. The dependent variable indicates for a given cell which of the four ownership/control regimes has positive exports.

To apply multinomial logit, we measure welfare for a given ownership/control regime choice relative to welfare for some base choice, which we select to be $\mathrm{W}(0,0)$. For convenience, we shall weight welfare by the inverse of $\sigma(A+\lambda B)^{2} / \gamma_{g}$, where $(A+\lambda B)^{2} / \gamma_{g}$ is the (first-best) 
value-added in the processing factory, and $\sigma$ is a parameter related to the variance of the extreme value error. ${ }^{12}$ Using the effort levels shown in Table 2, the relative welfare levels are:

$$
\begin{aligned}
& {\left[\frac{\mathrm{W}(1,0)-\mathrm{W}(0,0)}{\sigma(\mathrm{A}+\gamma \mathrm{B})^{2} / \gamma_{\mathrm{g}}}\right]=\frac{\phi^{2} \theta^{2}\left(1-\psi^{2}\right)}{\sigma}-\frac{1}{\sigma}\left[\phi^{2} \theta^{2} \psi^{2}+\left(\frac{\gamma_{\mathrm{g}}}{\gamma_{\mathrm{f}}}\right)-1\right]\left(\frac{\mathrm{P}}{\mathrm{A}+\lambda \mathrm{B}}\right)^{2},} \\
& {\left[\frac{\mathrm{W}(0,1)-\mathrm{W}(0,0)}{\sigma(\mathrm{A}+\gamma \mathrm{B})^{2} / \gamma_{\mathrm{g}}}\right]=\frac{\phi^{2} \theta^{2}}{\sigma}-\left(\frac{\gamma_{\mathrm{g}}}{\gamma_{\mathrm{f}}}\right) \frac{\phi^{2}(1-\theta)^{2} \psi^{2}}{\sigma}\left(\frac{\mathrm{P}}{\mathrm{A}+\lambda \mathrm{B}}\right)^{2}} \\
& -\frac{\phi^{2}}{\sigma}\left[\theta^{2} \lambda^{2}\left(\frac{\gamma_{\mathrm{f}}}{\gamma_{\mathrm{g}}}\right)+\psi^{2}(1-\theta)^{2}\right]\left[\frac{\mathrm{B}^{2} / \gamma_{\mathrm{g}}}{(\mathrm{A}+\lambda \mathrm{B})^{2} / \gamma_{\mathrm{f}}}\right] \\
& {\left[\frac{\mathrm{W}(1,1)-\mathrm{W}(0,0)}{\sigma(\mathrm{A}+\gamma \mathrm{B})^{2} / \gamma_{\mathrm{g}}}\right]=\frac{\phi^{2} \theta^{2}}{\sigma}-\frac{1}{\sigma}\left(\frac{\gamma_{\mathrm{g}}}{\gamma_{\mathrm{f}}}-1\right)\left(\frac{\mathrm{P}}{\mathrm{A}+\lambda \mathrm{B}}\right)^{2}} \\
& -\frac{\phi^{2}}{\sigma}\left[\theta^{2} \lambda^{2}\left(\frac{\gamma_{\mathrm{f}}}{\gamma_{\mathrm{g}}}\right)+\psi^{2}(1-\theta)^{2}\right]\left[\frac{\mathrm{B}^{2} / \gamma_{\mathrm{g}}}{(\mathrm{A}+\lambda \mathrm{B})^{2} \gamma_{\mathrm{f}}}\right] \text {. }
\end{aligned}
$$

The various terms appearing on the right of (17) reflect the reduction in welfare due to having efforts chosen below their first-best levels. Notice that these terms depend on two value-added ratios: $[P /(A+\lambda B)]^{2}$, which is the ratio of first-best value-added in input search relative to that in processing production (when they are both done by the manager); and $\left(\mathrm{B}^{2} / \gamma_{\mathrm{f}}\right) /\left[(\mathrm{A}+\lambda \mathrm{B})^{2} / \gamma_{\mathrm{g}}\right]$, which is the ratio of first-best value-added in marketing the final good relative to that in processing (where the former is done by the foreign firm and the latter by the manager). Our empirical measures of these value-added ratios are discussed next.

12 The variance of an extreme-value distribution is $\mu^{2} \pi^{2} / 6$ (Anderson, De Palma and Thisse, 1992, p. 40), whereas the MNL specification in (15) assumes that the variance is $\pi^{2} / 6$, so that $\mu=1$. Our assumption is that the variance parameter $\mu$ equals $\sigma(\mathrm{A}+\lambda \mathrm{B})^{2} / \gamma_{\mathrm{g}}$, so that by dividing each observation by this, we effectively obtain $\mu=1$. We do not attempt to identify $\sigma$, but shall treat it as a fixed parameter. 


\subsection{Data}

Data are from the Customs General Administration of the People's Republic of China and show processing imports and exports by year (1997-2002), 8-digit harmonized system (HS) product, origin or destination city-districts in China (including trade zone status), destination country (including whether goods are exported directly or through Hong Kong), customs regime (pure-assembly or import-and-assembly), and ownership type (foreign or Chinese-owned). In addition, we make use of import and re-export data for Hong Kong by year (1997-2001), source and destination country, and 8-digit HS product. The detail in these data approach that which might be available from a firm level dataset, even though the fundamental observation available to us is the 8-digit HS product, Chinese city-district, and destination market. For example, if there is a single factory processing “women's or girl's suit-type jackets of wool” in Pudong, Shanghai, operating in a SEZ, and exporting goods directly to the U.S., then the Chinese data would show its ownership and control regime along with its export value. However, if there are several such processing factories in Pudong (located in the same economic zone and exporting the same product directly to the U.S.), then the exports of each ownership and control regime represented there would be listed. Thus, a given city-economic zone-product-destination market cell might show positive exports for more than one type of contractual arrangement. ${ }^{13}$

To estimate the parameters of the welfare function, we need measures of the two valueadded ratios appearing on the right of (17). As discussed in the data appendix, we will measure the value-added in processing trade within China using an estimated input-output table that differs across provinces, and we shall measure the value-added in input search by the markups charged on goods re-exported from Hong Kong to China. From these two data sources the ratio

\footnotetext{
${ }^{13}$ In our data $82.7 \%$ of observations have positive exports in one ownership/control regime, $13.4 \%$ have positive exports in two regimes, $3.4 \%$ have positive exports in three regimes, and $0.5 \%$ have positive exports in four regimes.
} 
$[\mathrm{P} /(\mathrm{A}+\lambda \mathrm{B})]^{2}$ is constructed, which we refer to as the inbound value-added ratio, since it depends on the effort devoted to bringing inputs into China. It is more difficult to measure the valueadded in marketing the final good since this depends on the destination market for the processed good, but we attempt to do so using the markup on goods leaving China and re-exported through Hong Kong. The ratio of this to the value-added on processing trade within China is used to (imperfectly) measure $\left(\mathrm{B}^{2} / \gamma_{\mathrm{f}}\right) /\left[(\mathrm{A}+\lambda \mathrm{B})^{2} / \gamma_{\mathrm{g}}\right]$, which we refer to as the outbound value-added ratio, since it depends on the effort in marketing the final good exported from China.

Because of the errors involved in estimating the Hong-Kong markup and the input-output table for processing trade within China, both the value-added ratios are measured at the 1-digit SITC level rather than the 8-digit HS level; these ratios also vary across years, across provinces (since the processing input-output table differs across provinces), and across destination markets (for the outbound ratio). The coefficients of the two value-added ratios along with the intercept terms in (17) are estimated by multinomial logit, from which the underlying parameters $\phi, \theta, \psi$ are obtained once we specify $\sigma$ as a parameter. ${ }^{14}$ We correct the standard errors for the correlation across errors because the value-added ratios are measured across 1-digit SITC rather than 8-digit HS products. Our estimates will be sensitive to the Hong Kong markups that we use, and as discussed by Feenstra et al (1999), there are several methods available to estimate these. After reporting benchmark results, we investigate the sensitivity of the parameter estimates to alternative measures of the markups.

14 Because we do not accurately measure the ratio $\left(\mathrm{B}^{2} / \gamma_{\mathrm{f}}\right) /\left[(\mathrm{A}+\lambda \mathrm{B})^{2} / \gamma_{\mathrm{g}}\right]$ appearing in (17b) and (17c), we do not expect to identify the intercepts in those equations. So we rely on the single intercept term of (17a), together with the three coefficients of $[\mathrm{P} /(\mathrm{A}+\lambda \mathrm{B})]^{2}$, to measure the four parameters $\phi, \theta, \psi$, and $\left(\gamma_{\mathrm{g}} / \gamma_{\mathrm{f}}\right)$. It is readily shown that $\phi^{2}$ is proportional to the choice of $\sigma$, so we can only measure the relative magnitude of this parameter (across regions or time). The ratio $\left(\gamma_{\mathrm{g}} / \gamma_{\mathrm{f}}\right)$ is also quite sensitive to the choice of $\sigma$, so we do not report this parameter. The humancapital specificity parameter $\psi$ is independent of $\sigma$, while $\theta$ depends on $\sigma$ only slightly. 


\section{Empirical Results}

\subsection{Export Shares}

To evaluate the modularity of the welfare function nonparametrically, we report the average values of export-shares across the four factory-ownership and input-control regimes. In Table 3, the first two columns show export shares in the total sample, and the second two columns show export shares for all provinces expect those on the southern coast (i.e., excluding Shanghai, Zhejiang, Fujian, Guangdong, and Hainan). Reading down the diagonal of the first matrix, foreign control of the inputs (the pure-assembly regime) combined with foreign ownership of the factory accounts for an average of $8.3 \%$ of processing exports, while Chinese ownership of the factory and control of the inputs accounts for $14.6 \%$ of processing exports. Much more weight occurs on the off-diagonal, where Chinese control of the inputs (the importand-assembly regime) combined with foreign ownership of the factory accounts for $49.6 \%$ of exports, and foreign control of the inputs combined with Chinese ownership of the factory accounts for $27.1 \%$ of processing exports. Computing MOD as in (16), this is highly negative, confirming that dispersed control/ownership is more likely than concentrated control/ownership. Thus, in the full sample, the data support the submodularity of the surplus function. From Proposition 1, this is consistent with some combination of high value-added in input processing, low human-capital specificity, and a relatively high bargaining weight for foreign firms.

From Proposition 2, we expect the welfare function to be less submodular where productivity in export processing is lower or human-capital specificity is higher. In China, export processing activities are highly concentrated in coastal provinces. Given the relative absence of export processing in interior provinces, we might expect human-capital specificity to be higher in these regions. Managers or foreign firms who separate from their trading partners 
would presumably be less able to find an alternative partner in the interior than they would along the coast. In the second two columns of Table 3, we separate out processing exports for interior China. For the interior provinces we find that the MOD measure is positive rather than negative, indicating supermodular welfare. This appears to be consistent with Proposition 2.

One reason that coastal China has developed more export processing than the rest of the country is that over the last two decades trade policies have varied substantially across regions of the country. In the early stage of China's economic opening, the government permitted foreign trade and investment only in Special Economic Zones (SEZs) located in the southern coastal provinces of Guangdong and Fujian. In the mid to late 1980s, the government expanded the number of regions in which foreign trade and investment were permitted. By the 1990s, foreign trade and investment were allowed (subject to government approval) throughout the country (Demurger et al, 2001). Still, much export activity continued to be concentrated in SEZs. ${ }^{15}$ Advantages to being in a zone may include expedited treatment by customs of imported inputs and exported outputs, more freedom to import or export goods directly rather than through stateowned foreign trade corporations, greater opportunities to retain foreign exchange earnings, and access to various types of tax incentives. There are is also a separate court system set up to handle civil and commercial legal cases in trade zones (Wang, 2000).

Being in a SEZ may affect the choice of input-control and factory-ownership regime in a variety of ways. Since SEZs are the center of import and export activities in China, it might be relatively easy for a foreign firm or Chinese factory with a presence in an SEZ to find a new export supplier or foreign buyer. We hypothesize that this would lower the specificity of human-

\footnotetext{
${ }^{15}$ SEZs have been succeeded by second and third generation trade and development zones, including bonded areas, Economic and Technological Development Areas, and Hi-Technology Development Areas. At risk of blurring definitions, we refer to all of these zones as SEZs. These zones are managed by provincial governments and so may exhibit regional variation in their organization and effectiveness.
} 
capital investments by factory managers and foreign buyers, and by Proposition 2, would make concentrated input-control and factory-ownership less likely inside SEZs than outside SEZs. To evaluate this, Table 4 replicates the results in Table 3 breaking out processing exports by whether or not they are produced in one of China's Special Economic Zones (SEZs). Being inside and SEZ puts over $75 \%$ of the export mass in the lower-left cell, with foreign ownership but Chinese control of the inputs. Outside the SEZs, there is $44 \%$ of the export share with foreign ownership and Chinese control, but another 32\% with the reverse case of Chinese ownership and foreign control of the input, so again the preponderance of export mass is on the off-diagonal of Table 4 . So being outside the SEZ does affect the type of contract used in outsourcing, but the modularity measures within or outside the SEZ are not that different.

Another useful way to split the sample is according to whether the processing exports from China are re-exported through Hong Kong or not. Re-exports are not simply goods transshipped through Hong Kong; rather, they are goods that clear customs in Hong Kong and that are taken into possession (and subject to intermediation services) by firms there. Hong Kong traders typically grade them according to quality, package and label them, and arrange for their shipment to final destination markets (Sung, 1991). As compared to direct exports from China, we conjecture that Hong Kong firms have a higher relatively high marginal productivity of investment (B) in export processing activities and relatively low specificity of human-capital investments $(\psi)$. By Proposition 2, we then expect export processing involving Hong Kong to exhibit more dispersed ownership and control. Table 5 separates Chinese processing exports into those shipped directly to destination markets and those re-exported through Hong Kong. For Hong Kong re-exports, there is more mass along the off-diagonal in dispersed ownership and 
control regimes. Thus, for re-exports through Hong Kong, MOD is more negative, as is again consistent with Proposition 2.

Lastly, we investigate how ownership and control differs across various industries. In Tables 6 and 7 we contrast two low value-added industries (apparel and footwear) with two high value-added industries (office machines and electrical machinery). ${ }^{16}$ In Table 6, apparel has export shares that are rather evenly spread across the four ownership/control regimes (though somewhat less in Chinese ownership and control), and its measure of modularity MOD is closer to zero than the overall sample in Table 3. Footwear also has a less negative measure of modularity, though it is closer to the overall sample. From Proposition 1, industries are less likely to be submodular when the value-added in input processing is low, and this is true for both these industries. In contrast, office machines in Table 6 has nearly $70 \%$ of its export share in the Chinese control/foreign ownership regime, and the modularity measure MOD is much more negative than for the entire sample. Electrical machinery is also more submodular than the overall sample. These are both high value-added industries, so the lower value of MOD is consistent with Propositions 1 and 2.

The differing pattern of ownership/control across industries may account in part for the differing magnitude of MOD across regions of China: the coastal provinces have roughly equal processing exports within SITC 7 (which includes office machines and electrical machinery) and outside of SITC 7, whereas the interior provinces have four times more exports outside of SITC 7, and especially within SITC 8 (which includes apparel, footwear, and toys). In our parametric estimation we will control for differences in value-added across industries by using this as an

\footnotetext{
${ }^{16}$ Over the sample period, apparel accounts for $16.9 \%$ of China's total processing exports, electrical machinery accounts for $11.7 \%$, office machines accounts for $11.4 \%$, and footwear accounts for $6.5 \%$, making these the first, third, fourth, and sixth largest Chinese industries for processing exports (the second and fifth largest industries are jewelry and telecommunications and sound recording equipment).
} 
independent variable. In addition, we allow for other differences across coastal and inland provinces by letting the model parameters $\psi$ and $\phi$ differ across regions.

\subsection{Parametric Estimation Results}

We turn now to the estimation of the model parameters: $\psi$, the specificity of human capital in a factory manager-foreign firm relationship; $\theta$, the bargaining weight for foreign firms; and $\phi$, the probability that contracts will be unenforceable. The latter parameter is very sensitive to our choice of $\sigma$, which is related to the variance of the extreme-value distribution. We choose $\sigma=0.1$ to ensure that $\phi$ lies between zero and unity, and focus on the relative magnitude of this parameter across various dimensions of the data rather than its absolute level. ${ }^{17}$

In Table 8, we report the results from MNL estimation of the three equations in (17). With six years of data (1999 - 2002) and thirty Chinese provinces, we can allow parameters to change over time and across regions. We adopt a parsimonious specification whereby the coefficients of the two valued-added ratios appearing on the right of (17) have constant coefficients, whereas the intercept terms vary across inland and coastal regions and also years. In addition, we allow for interaction terms between the four coastal regions (northern provinces; those around Beijing; those around Shanghai; and southern provinces) and the two time periods 1997-99 and 2000-02. The usefulness of this fixed-effects specification will be apparent when we discuss the parameter estimates.

In Table 8, the sign pattern of the coefficients in the three MNL equations meets our expectations from (17). For example, in the first regression, the inbound value-added ratio has a negative coefficient in (17a) provided that $\left(\gamma_{\mathrm{g}} / \gamma_{\mathrm{f}}\right)$ is not too small, and this negative sign is

\footnotetext{
17 As discussed in note 14 , the $\gamma_{\mathrm{g}} / \gamma_{\mathrm{f}}$ is also quite sensitive to the choice of $\sigma$, so we do not report this parameter, which is typically slightly greater than unity.
} 
confirmed in the estimated equation (17a) in Table 8. The outbound value-added ratio does not appear at all in (17a), and its estimated coefficient in Table 8 is very small. The intercept term is positive in (17a), where it equals $\phi^{2} \theta^{2}\left(1-\psi^{2}\right) / \sigma$, and also in the estimate of Table 8. Our inclusion of Hong-Kong and SEZ indicator variables, as well as the regional indicator variables for the four coastal regions, clearly affects the estimate of the intercept term in Table 8 and therefore affects the implied parameters. Using equations (17) and the estimates from Table 8, we can solve for the implied parameters $\psi, \phi$ and $\theta$, as reported in Table 9 . We also compute standard errors by bootstrapping equations (17) with 100 replications. For convenience, we do not report the standard error for each estimate and region, but instead indicate the maximum standard error across regions.

From Table 9, we see that the estimates of $\psi$, the degree of human-capital specificity, are highest in Beijing and lowest in the southern coast. Since this parameter reflect the loss in the return to human-capital investments when bargaining breaks down, lower values of $\psi$ may indicate a "thicker" labor market and stronger outside options for the Chinese managers. We find it highly plausible human-capital specificity is lowest in the southern coastal provinces of Guangdong, Fujian and Hainan Island due to the concentration of export activity in these regions. It is somewhat surprisingly that this parameter is highest in Beijing, though the difference between Beijing and the northern or inland provinces is very small in the 2000-02 period, whereas the southern coastal provinces still have a markedly lower value of $\psi$, indicating less human-capital specificity. Just below the estimates of $\psi$ for each time period, we report the range of these parameters across regions. Generally, these ranges are reduced in the 2000-02 period as compared to 1997-99. These results are suggestive of labor markets that are becoming more integrated within and across regions over time. 
In addition, the estimates of $\psi$ depend on whether the goods are processed in SEZ or not, and whether they are re-exported through Hong Kong or not. Comparing the estimates in the first two columns of Table 9 with those in the second two columns, we see that direct exports have slightly higher estimates of $\psi$ than do re-exports through Hong-Kong. That is, by not using Hong-Kong traders to handle processed exports, Chinese entrepreneurs or foreign firms face slightly higher project specificity of human-capital investments (presumably because the Hong Kong traders can help arrange a new match). This human-capital specificity is increased further when processing occurs outside of SEZ. An exception to this rule occurs for the southern coastal provinces, where the loss in returns to human-capital investments remains close to 0.22 (or $22 \%$ ) regardless of whether processing occurs in SEZ or whether the goods are re-exported through Hong Kong. That estimate for Fujian, Guangdong and Hainan compares with the range $0.28-$ 0.51 (or $28-51 \%$ ) for the other regions and years.

Next in Table 9 we report the estimates of $\phi$, which is the probability that a contract cannot be enforced so that Nash bargaining is used. Recall that the absolute magnitude of this parameter depends on $\sigma$, which is related to the variance of the extreme-value distributions in the MNL specification. We have chosen $\sigma=0.1$ so that $\phi$ lies between zero and unity, and focus on the relative magnitude of this parameter rather than its absolute level. Our estimates of $\phi$ are lowest in Beijing, suggesting the highest degree of legal enforcement there. While we have no direct evidence on legal institutions across provinces, there is data on the level of "trust" that businesses perceive within each province, from Ke and Zhang (undated). ${ }^{18}$ According to these authors, Beijing and Shanghai rank as the most trustworthy locations. Our estimates accord with

18 These authors received a response from over 5,000 businesses on the question: "From your experience, which five regions do you consider most trustworthy? List from high to low." 
theirs for Beijing, but not for Shanghai, where our estimates of $\phi$ in Table 9 are higher than for Beijing. More surprisingly, our estimates shown the highest value of $\phi$ in the southern coastal provinces. We would not have expected to have the highest probability of Nash bargaining (and lowest likelihood of legal enforcement) in these locations. Ke and Zhang rank Guangdong as $4^{\text {th }}$ in terms of "trust," Fujian as $11^{\text {th }}$, but Hainan at $30^{\text {th }}$ out of 31 provinces or autonomous regions (including Chongqin, which is a newly added $31^{\text {st }}$ region). While our finding that the southern coastal provinces have a much higher value of $\phi$ is surprising, we note that the disparity between these provinces and Beijing is somewhat lower in the 2000-02 period than in 1997-99. In other words, there is evidence of regional convergence in legal institutions over time.

Lastly in Table 9 we report the estimate of $\theta$, the Nash bargaining weight for foreign firms, which is 0.69 (standard error of 0.12 ) across all regions and time periods. It turns out that $\theta$ depends only on the slope coefficients of the inbound and outbound value-added ratios, so in our specification it does not vary with region or time period, as do $\psi$ and $\phi$. However, the estimates of the bargaining weight would be sensitive to the measurement of the Hong Kong markups, used to compute the inbound and outbound value-added ratios. Feenstra et al (1999) describe three methods for computing markups, and method $\mathrm{C}$ is used in Tables 6 and $7 .{ }^{19}$ By way of sensitivity analysis, we re-estimate (17) using the alternative methods A and B. In Table 10 we report parameter estimates using these methods, focusing on 2000-02 for convenience.

Considering first the estimates of $\psi$, method B gives estimates that are larger than those for methods A or C. Despite the differences in magnitude, the overall pattern of estimates across

19 These methods are described in the data appendix. The difficulty in measuring the re-export markups is that Hong Kong re-exports are distinguished by destination country whereas Hong Kong imports are not, so the bundle of goods differs even at the 8-digit HS level. Method A compares the Hong Kong import unit-value for each HS product to the unit-value for re-exports to a destination country, whereas method B compares the Hong Kong import unit-value to the unit-value for all re-exports (regardless of destination country). Method $\mathrm{C}$ attempts to correct the import unit-value to reflect the ultimate destination country for the re-exports. 
regions is similar in Table 9 and 8. In all cases, Beijing has the highest estimate of $\psi$ and the southern coastal provinces have the lowest, though the range of estimates across regions in Table 10 is somewhat smaller than in Table 9. Again, the lower values of $\psi$ for the southern coastal provinces indicate less human-capital specificity and "thicker" labor market there.

The estimates of $\phi$ in Table 10 are also larger than those reported in Table 9, and in some cases $\phi$ exceeds unity. This could be readily corrected by choosing a lower value of $\sigma$, whereas we have maintained $\sigma=0.1$ in both Tables 7 and 8 . The absolute magnitude of $\sigma$ is not that relevant, but its relative magnitude across regions is still of interest. Again, we obtain the same pattern of estimates in Table 10 and in our benchmark results of Table 9: $\phi$ is lowest in Beijing, indicated the greatest degree of legal enforcement of contracts there, and highest in the southern coastal provinces. Evidently, this pattern is not sensitive to the precise measure of the Hong Kong markups that we use in constructing the value-added ratios.

Finally in Table 10 we report the estimate of $\theta$, which is the Nash bargaining weight for the foreign firm. It varies between 0.42 and 0.65 in Table 10, which is somewhat lower than the estimates of 0.69 in our benchmark results. This range of estimates includes the value 0.5 , which corresponds to simple Nash bargaining as used by Grossman and Hart (1986). It appears that this simple bargaining rule is adequate to account for the contractual choices observed in export processing in China, provided that differences in human capital-specificity and contractual enforcement across regions are also incorporated.

\section{Conclusions}

This paper reports a new empirical finding: that the allocation of ownership and control in processing exports of China tends to be shared between foreign and local parties, with foreign firms likely to have (at least partial) ownership in the Chinese plant, but the Chinese parties 
having control over input-purchase decisions. Based on anecdotal evidence, we expect that this pattern might apply in other developing countries as well, such as India. A goal of our paper has been to reconcile this finding with available theories of the ownership/control structure within a firm. We have drawn on the property-rights model due to Grossman and Hart (1986) and Hart and Moore (1990), while also including simple contracting costs into the model, in the spirit of the Holmstrom-Milgrom incentive-systems (IS) framework. To conclude, it is useful to contrast these two models to see to which framework our results are closest.

Holmstrom and Milgrom show that under certain conditions the IS model leads to a complementarity in the allocation of ownership/control instruments, so that these instruments tend to be given to the same party. In our simple model of outsourcing, we find that the PR model leads to that outcome when value-added in the factory is low or the specificity of humancapital investments is high. But the PR model leads to the alternative arrangement with a sharing of the ownership/control instruments between the parties when value-added is high, or human-capital specificity is low. The evidence from China strongly supports the finding that ownership and control is divided between the parties, and more so as we consider subsets of the data that focus on exports through Hong Kong, or that exclude the interior provinces: in these cases, an even greater magnitude of exports occur in the foreign-ownership/local-input-control regime. The finding that ownership and control is divided between parties therefore supports a PR framework with a low or moderate degree of human-capital specificity, meaning that the effect of outside options on incentives becomes very important. There is some evidence of regional convergence in the contractual environment, which would be consistent with a gradual harmonization of legal institutions and equalization of access to world markets across regions. 


\section{Data Appendix}

\section{A. Estimating Value Added in Chinese Export Processing}

An initial measure of value-added in Chinese export processing is the difference between the value of processing exports and processing imports (relative to processing exports). As shown at the bottom of column (3) in Table A1, average value-added is $36 \%$ over all products and years 1997-2002. It is not possible to measure this by individual harmonized system (HS) products, however, since it is not known what other HS products they use as inputs. Even if we aggregate the trade data to the 1-digit SITC level, as shown in Table A1, we see that for a number of SITC categories the value of processing imports exceeds exports: obviously, these imports are being used to produce exports in alternative SITC products. In order to measure the value-added within HS or SITC products, we therefore cannot rely on the difference between processing exports and imports. Instead, we make use of the provincial-level processing trade data at the 1-digit SITC level to estimate an input-output table between SITC categories.

There is considerable variation in the processing trade by 1-digit SITC industries across provinces. In Table A2, we compare SITC 7 (machinery and transport equipment, which includes office machines) with all other SITC categories, across provinces. For the coastal provinces, there is roughly equal processing exports within SITC 7 and outside this category. But the inland provinces have about four times as much processing exports outside of this category. The most important sector for the inland provinces is SITC 8 (miscellaneous manufactured articles, which includes apparel, footwear and toys).

Making use of the variation in processing trade across provinces, we estimate an inputoutput table for processing trade, as discussed in section B. This input-output table differs across provinces and years, reflecting the productivity with which processing imports are used. By construction, the demand for processing imports from the input-output table exactly equals actual imports in each province, year, and 1-digit SITC product. The average value-added estimates by 1-digit SITC industries are shown in column (4) of Table A1.

We do not obtain a value-added estimate in SITC 0 (food and live animals) that is significantly different from zero, and we are also unable to estimate value-added in SITC 9 (special commodities and transactions). There is little trade in either of these industries. But for the remaining 1-digit SITC industries, the value-added estimates in Table A1 appear plausible. The industries with the greatest processing exports are SITC 6 (manufactured goods), 7 (machinery and transport equipment) and 8 (miscellaneous manufactured goods). We obtain relatively low value-added of $16 \%$ in SITC 6 and 8, and higher value-added of $55 \%$ in SITC 7. As described by Yeats (2001), SITC 7 includes a number of individual products and their parts, such as: automobiles and their parts; computers and their parts; various types of machinery and their parts; etc. So as a rough check on our value-added estimate of $55 \%$ from the input-output table, we can compare this to value of processing exports and processing imports (relative to processing exports), obtaining $50 \%$ as shown in column (3). This is quite close to our inputoutput estimate of $55 \%$ for this industry in column (4), giving us added confidence in the estimated input-output table. 


\section{B. Input-Output Table for Processing Trade}

Denote processing export industries at the 1-digit SITC level by $\mathrm{i}=1, \ldots, \mathrm{N}$, and processing import industries at the 1-digit SITC level by $\mathrm{j}=1, . ., \mathrm{N}$. Let the $(\mathrm{NxN})$ matrix $\mathrm{A}^{\mathrm{kt}}=\left[\mathrm{a}_{\mathrm{ij}}^{\mathrm{kt}}\right]^{\prime}$ denote the amounts of processing imports $\mathrm{j}$ needed per dollar of processing exports $\mathrm{i}$ in province $\mathrm{k}$ and year $\mathrm{t}$. The columns of this matrix denote processing exports and the rows are imported inputs. Let $\mathrm{X}^{\mathrm{kt}}$ denote the $(\mathrm{Nx} 1)$ vector of processing exports in each industry for year $\mathrm{t}$ and province $\mathrm{k}$, and let $\mathrm{M}^{\mathrm{kt}}$ denote the $(\mathrm{Nx} 1)$ vector of demands of processing imports. These are related by $\mathrm{M}^{\mathrm{kt}} \equiv \mathrm{A}^{\mathrm{k}} \mathrm{X}^{\mathrm{kt}}$. We model the elements of $\mathrm{A}^{\mathrm{k}}$ as:

$$
\mathrm{a}_{\mathrm{ij}}^{\mathrm{k}}=\exp \left(\mathrm{b}_{\mathrm{ij}}^{-2}\right) \delta_{\mathrm{j}}^{\mathrm{kt}}
$$

where $0 \leq \exp \left(\mathrm{b}_{\mathrm{ij}}^{-2}\right) \leq 1$ and $\delta_{\mathrm{j}}^{\mathrm{kt}}$ is a parameter indicating the productivity of imported input $\mathrm{j}$ in province $\mathrm{k}$ and year $\mathrm{t}$ : $\delta_{\mathrm{j}}^{\mathrm{kt}}>1$ means that more of input $\mathrm{j}$ is needed, so it is less productive, and conversely when $\delta_{\mathrm{j}}^{\mathrm{kt}}<1$.

We estimate $b_{\mathrm{ij}}$ and $\delta_{\mathrm{j}}^{\mathrm{kt}}$ in a two-step procedure. In the first step, we treat $\delta_{\mathrm{j}}^{\mathrm{kt}}$ as unknown random variables that are distributed independently of the processing exports $X_{i}^{\mathrm{kt}}$. Then using (A1) and $\mathrm{X}^{\mathrm{kt}} \equiv \mathrm{A}^{\mathrm{k}} \mathrm{Y}^{\mathrm{kt}}$, we estimate $\mathrm{b}_{\mathrm{ij}}$ from the nonlinear regressions:

$$
\mathbf{M}_{\mathrm{j}}^{\mathrm{kt}}=\sum_{\mathrm{i}=1}^{\mathrm{N}}\left[\exp \left(\mathrm{b}_{\mathrm{ij}}^{-2}\right) \delta_{\mathrm{j}}^{\mathrm{kt}}\right] \mathrm{X}_{\mathrm{i}}^{\mathrm{kt}}=\sum_{\mathrm{i}=1}^{\mathrm{N}} \exp \left(\mathrm{b}_{\mathrm{ij}}^{-2}\right) \mathrm{X}_{\mathrm{i}}^{\mathrm{kt}}+\varepsilon_{\mathrm{j}}^{\mathrm{kt}}, \quad \mathrm{j}=1, \ldots, \mathrm{N}
$$

where $\varepsilon_{\mathrm{j}}^{\mathrm{kt}} \equiv \sum_{\mathrm{i}=1}^{\mathrm{N}}\left[\left(\delta_{\mathrm{j}}^{\mathrm{kt}}-1\right) \exp \left(\mathrm{b}_{\mathrm{ij}}^{\mathrm{k}}\right)\right] \mathrm{X}_{\mathrm{i}}^{\mathrm{kt}}$ is a random error with mean zero, which is independent of the processing outputs $\mathrm{X}_{\mathrm{i}}^{\mathrm{kt}}$ by virtue of the assumption that $\delta_{\mathrm{i}}^{\mathrm{kt}}$ is also. These 10 regressions in (A2) are run over six years and 30 Chinese provinces, for a total of 180 observations. The estimates of $\exp \left(\mathrm{b}_{\mathrm{ij}}^{-2}\right)$ are shown in Table A3, where to assist in convergence we have restricted the coefficients of SITC export industries 1 and 2, and 3 and 5, to be the same.

Let $\mathrm{B} \equiv \exp \left(\hat{\mathrm{b}}_{\mathrm{ij}}^{-2}\right)$ denote the matrix of estimates obtained. In the second step, we treat $\delta_{\mathrm{j}}^{\mathrm{kt}}$ as fixed effects estimated so that the relation $\mathrm{M}^{\mathrm{kt}} \equiv \mathrm{A}^{\mathrm{kt}} \mathrm{X}^{\mathrm{kt}}$ holds precisely in each province and year. Letting $\mathrm{D}^{\mathrm{kt}} \equiv \operatorname{diag}\left(\hat{\delta}_{\mathrm{j}}^{\mathrm{kt}}\right)$ denote the diagonal matrix, this relation can be written as:

$$
\mathrm{M}^{\mathrm{kt}}=\mathrm{D}^{\mathrm{kt}} \mathrm{BX} \mathrm{kt}^{\mathrm{kt}}
$$


Let $\hat{\mathrm{M}}^{\mathrm{kt}} \equiv \mathrm{BX} \mathrm{kt}^{\mathrm{kt}}$ denote the predicted imported inputs if province $\mathrm{k}$ had the input-output matrix B. Then writing out (A3) in terms of the components of each vector, the elements of D are:

$$
\hat{\delta}_{\mathrm{j}}^{\mathrm{kt}}=\mathrm{M}_{\mathrm{j}}^{\mathrm{kt}} / \hat{\mathrm{M}}_{\mathrm{j}}^{\mathrm{kt}}
$$

Thus, if province $\mathrm{k}$ has lower actual imports than predicted imports of input $\mathrm{j}$, then $\hat{\delta}_{\mathrm{i}}^{\mathrm{kt}}<1$ indicates above-average productivity of this input. Using the estimates in (A4), we obtain $a_{i j}^{k}=\exp \left(b_{i j}^{-2}\right) \delta_{j}^{k t}$, which are the components of the input-output matrix. The values of this matrix when averaged across provinces and years are shown in Table A4.

Since $\mathrm{a}_{\mathrm{ij}}^{\mathrm{kt}}$ is the amount of processing imports $\mathrm{j}$ needed for one dollar of processing export in industry $i$, then the value-added in industry $i$ is $\left(1-\sum_{j=1}^{N} a_{i j}^{k t}\right)$. This is shown in the last row of Table A4. Note that value-added in SITC industry 0 (food and live animals) is insignificantly different from zero, and we do not obtain a value-added estimate for SITC industry 9 (commodities and transactions). These are industries in which there is relatively little processing trade. Otherwise, the value-added estimates in Table A4 appear reasonable.

\section{Measurement of Hong Kong Markups}

The measurement of these Hong Kong markups is discussed in Feenstra et al (1999), and is based on a comparison of unit-values for Hong Kong imports and re-exports of disaggregate commodities (as the 8-digit HS level). This comparison is complicated, however, because when a good is imported into Hong Kong, it is not known whether it is intended for the domestic market or for re-export to some destination market. So comparing the import unit-value to the unit-value for re-exports to China involves some error, and sometimes the computed Hong Kong markups can be negative rather than positive. ${ }^{20}$

Feenstra et al (1999) discuss several alternative methods for the markups calculation, and in Table A5 we summarize method A, B, and C for goods entering China, and method A for goods leaving China, averaged over 1-digit SITC categories. Consider first goods entering China from Hong Kong (the "inbound" markups). Method A compares the import unit-value of all Hong Kong imports of each HS product to the unit-value for re-exports to China, whereas method B compares the unit-value of all Hong Kong imports to the unit-value of all re-exports (of which about $80 \%$ on average go to China). ${ }^{21}$ From columns (1) and (2) in Table A5, the average markups is only $1.4 \%$ over all products and years using method $\mathrm{A}$, and $4.1 \%$ using method B. Method C attempts to improve on these estimates by using only 8-digit HS products for which the quantity of imports into Hong Kong are at least $90 \%$ of the quantity of re-exports to China, i.e., these HS products are nearly entirely destined for China. From column (3), the average markup using method $\mathrm{C}$ is $4.2 \%$, but there are some substantial differences in the 1-digit

20 Feenstra and Hanson (2002) argue that negative markups might be a genuine feature of the market, rather than just measurement error, due to "quality sorting" of goods in Hong Kong.

21 We are excluding re-exports that originate in China from these calculations. 
markups across the various methods. We choose method $\mathrm{C}$ for our benchmark estimates because it appears to give the most accurate comparison of goods imported into Hong Kong and reexported to China. In cases where we obtain negative markups for the 1-digit SITC categories, these products are omitted from the calculation of the value-added ratios, and from our regression estimation.

Turning to the markups on goods originating in China and re-exported from Hong Kong (the "outbound" markups), these are calculated for each destination market. In column (4) of Table A5 we report the average value of these markups across destination markets, and across years. It can be seen that the outbound markups are much higher than the inbound markups, with an average value of $16.7 \%$. We did not use method $\mathrm{B}$ (which would average across destination markets) or any method $\mathrm{C}$ for the outbound markups.

To compute the ratio of Hong-Kong markups to the Chinese value-added, we first reexpress both relative to a common denominator, which is the value of goods flowing from Hong Kong to China, i.e. Chinese imported inputs. Thus, the estimate of Chinese value-added are reexpressed as $\left(1-\sum_{\mathrm{j}=1}^{\mathrm{N}} \mathrm{a}_{\mathrm{ij}}^{\mathrm{kt}}\right) / \sum_{\mathrm{j}=1}^{\mathrm{N}} \mathrm{a}_{\mathrm{ij}}^{\mathrm{kt}}$. Then taking the ratio of the "inbound" markups to Chinese value-added we obtain the inbound value-added ratio $[\mathrm{P} /(\mathrm{A}+\lambda \mathrm{B})]^{2}$ that appears on the right of (17). This explanatory variable varies across 1-digit SITC industries, provinces, and years, and is alternatively calculated using methods A, B and C for the "inbound" markups. Taking the ratio of the "outbound" markups to Chinese value-added we obtain the outbound value-added ratio $\left(\mathrm{B}^{2} / \gamma_{\mathrm{f}}\right) /\left[(\mathrm{A}+\lambda \mathrm{B})^{2} / \gamma_{\mathrm{g}}\right]$, which varies across 1 -digit SITC industries, provinces, years, and destination markets. 
Table A1: Chinese Processing Trade by SITC Industry (\$million and percent, average 1997-2002)

\begin{tabular}{cccc}
\hline $\mathbf{( 1 )}$ & $\mathbf{( 2 )}$ & $\mathbf{( 3 )}$ & $\mathbf{( 4 )}$ \\
Processing & Processing & $\frac{(1)-(2)}{(1)}$ & Value- \\
Exports & Imports & added \\
$(\$$ million $)$ & $(\$$ million $)$ & (percent) & (percent) \\
\hline
\end{tabular}

SITC 0 - Food and live animals

$\begin{array}{llll}2,467 & 1,249 & 49 \% & 0\end{array}$

SITC 1 - Beverages and tobacco

$\begin{array}{llll}64 & 6 & 91 \% & 63 \%\end{array}$

SITC 2 - Crude materials, inedible, except fuels

$295 \quad 4,568 \quad-1,448 \% \quad 63 \%$

SITC 3 - Mineral fuels, lubricants and related materials

$602 \quad 1,006 \quad-67 \% \quad 67 \%$

SITC 4 - Animal and vegetable oils, fats and waxes

$\begin{array}{llll}160 & 224 & -40 \% & 43 \%\end{array}$

SITC 5 - Chemicals and related products

$\begin{array}{llll}2,416 & 11,858 & -391 \% & 67 \%\end{array}$

SITC 6 - Manufactured goods

$\begin{array}{llll}16,081 & 25,750 & -60 \% & 16 \%\end{array}$

SITC 7 - Machinery and Transport Equipment

$\begin{array}{llll}60,443 & 30,486 & 50 \% & 55 \%\end{array}$

SITC 8 - Miscellaneous manufactured articles $\begin{array}{llll}45,949 & 6,626 & 86 \% & 16 \%\end{array}$

SITC 9 - Special commodities and transactions

$\begin{array}{llll}77 & 829 & -977 \% & \text { n.a. }\end{array}$

$\begin{array}{lllll}\text { Total } & 128,553 & 82,600 & 36 \% & 36 \%\end{array}$

\section{Notes:}

Column (3) reports (processing exports - processing imports)/processing exports for each 1-digit SITC industry. The negative values reported for many industries indicate that the processing inputs are used elsewhere. The value-added estimates in column (4) are measured with the input-output table reported in section B, and Tables A2 and A3. This table differs across 1-digit SITC industries, provinces and years, so all values shown are averages. 
Table A2: Chinese Processing Trade by Provinces and SITC Industry (\$million and percent, average 1997-2002)

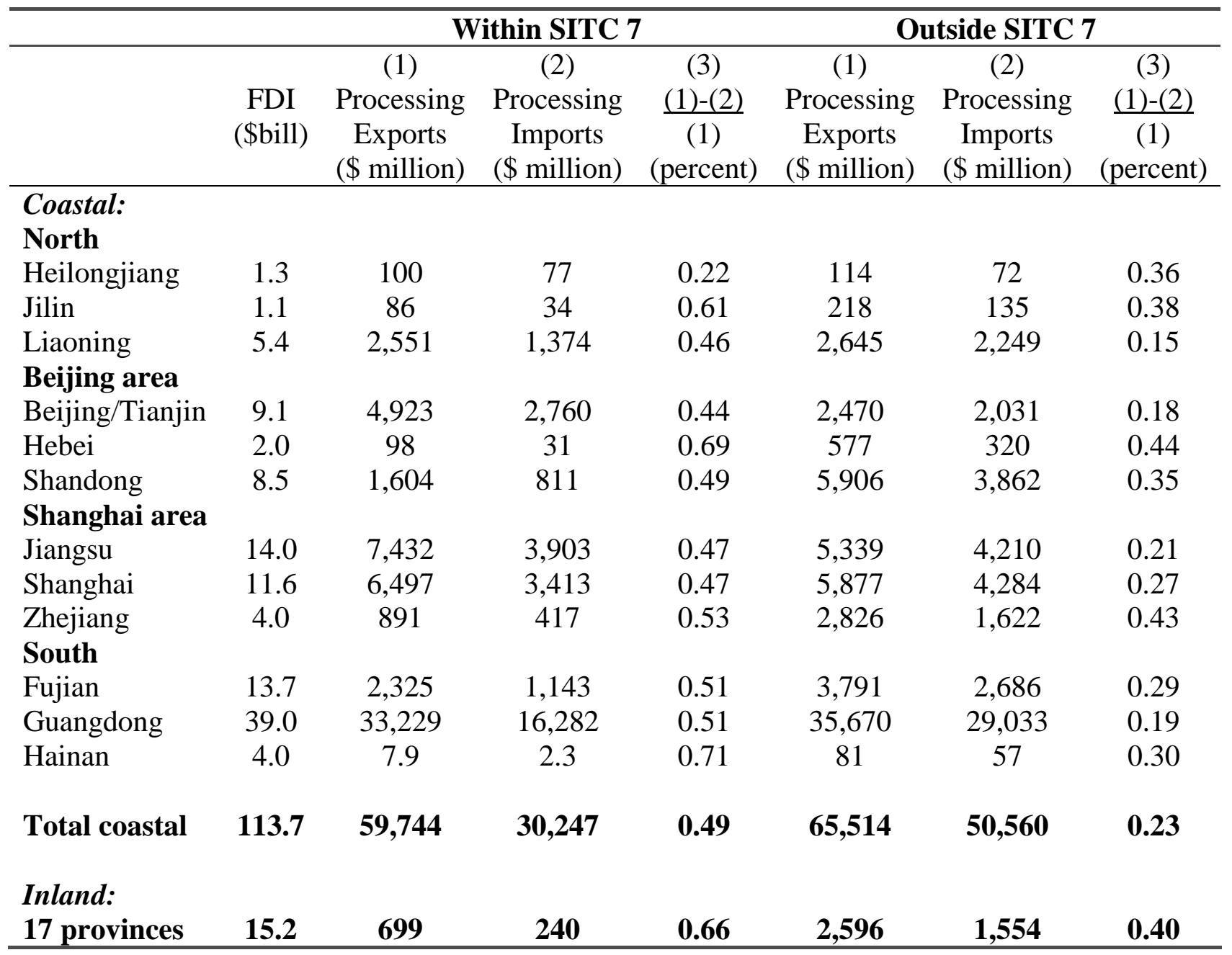

\section{Notes:}

Column (3) reports (processing exports - processing imports)/processing exports for each province, for SITC 7 and all other SITC. We combine Beijing and the neighboring industrial district of Tianjin, while Guangxi is treated as an inland province even though it has some coastline in the south of China. 
Table A3: First-step estimates of $\exp \left(\mathrm{b}_{\mathrm{ij}}^{-2}\right)$ for input-output table

\begin{tabular}{|c|c|c|c|c|c|c|c|c|c|c|}
\hline & & & & & & rocess & Expor & & & \\
\hline & SITC: & 0 & 1 & 2 & 3 & 4 & 5 & 6 & 7 & 8 \\
\hline & 0 & 0.563 & & & & & & & & \\
\hline & 1 & & 0.007 & 0.007 & & & & & & \\
\hline & 2 & 0.277 & & & & 0.180 & & 0.176 & & \\
\hline & 3 & 0.081 & & & 0.277 & & 0.277 & & & \\
\hline Processing & 4 & & 0.325 & 0.325 & & & & & & 0.002 \\
\hline Imports & 5 & & & & & & & & 0.010 & 0.278 \\
\hline & 6 & & & & 0.062 & & 0.062 & 0.218 & & 0.487 \\
\hline & 7 & & & & & & & 0.379 & 0.376 & 0.047 \\
\hline & 8 & 0.095 & & & & & & 0.020 & 0.066 & 0.043 \\
\hline & 9 & & & & & 0.478 & & & & 0.024 \\
\hline
\end{tabular}

Table A4: Second-step estimates of $\mathrm{a}_{\mathrm{ij}}^{\mathrm{k}}=\exp \left(\mathrm{b}_{\mathrm{ij}}^{-2}\right) \delta_{\mathrm{j}}^{\mathrm{kt}}$ for input-output table

\begin{tabular}{|c|c|c|c|c|c|c|c|c|c|c|}
\hline & & & & & & rocess & Export & & & \\
\hline & SITC: & 0 & 1 & 2 & 3 & 4 & 5 & 6 & 7 & 8 \\
\hline & 0 & 0.506 & & & & & & & & \\
\hline & 1 & & 0.016 & 0.016 & & & & & & \\
\hline & 2 & 0.357 & & & & 0.232 & & 0.227 & & \\
\hline & 3 & 0.079 & & & 0.269 & & 0.269 & & & \\
\hline Processing & 4 & & 0.349 & 0.349 & & & & & & 0.003 \\
\hline Imports & 5 & & & & & & & & 0.009 & 0.247 \\
\hline & 6 & & & & 0.061 & & 0.061 & 0.215 & 0.000 & 0.481 \\
\hline & 7 & & & & & & & 0.373 & 0.370 & 0.046 \\
\hline & 8 & 0.097 & & & & & & 0.020 & 0.067 & 0.043 \\
\hline & 9 & & & & & 0.336 & & & & 0.017 \\
\hline & Sum & 1.038 & 0.366 & 0.366 & 0.330 & 0.567 & 0.330 & 0.835 & 0.446 & 0.837 \\
\hline & Value-added & -0.038 & 0.634 & 0.634 & 0.670 & 0.433 & 0.670 & 0.165 & 0.554 & 0.163 \\
\hline
\end{tabular}

Note: These estimates are averaged across provinces and years. 
Table A5: Hong Kong Markups by SITC Industry (percent, average 1997-2001)

\begin{tabular}{cccc}
\hline \multicolumn{3}{c}{ Inbound to China } & $\begin{array}{c}\text { Outbound } \\
\text { from China }\end{array}$ \\
\hline Markup & Markup & Markup & Markup \\
Method A & Method B & Method C & Method A \\
(percent) & (percent) & (percent) & (percent) \\
\hline
\end{tabular}

SITC 0 - Food and live animals

$$
-7.1 \% \quad-4.3 \% \quad-4.0 \% \quad 20.9 \%
$$

SITC 1 - Beverages and tobacco
$5.1 \%$
$16.5 \%$
$8.4 \%$
$63.3 \%$

SITC 2 - Crude materials, inedible, except fuels
$0.0 \%$
$0.7 \%$
$1.2 \%$
$18.5 \%$

SITC 3 - Mineral fuels, lubricants and related materials
$3.4 \%$
$7.7 \%$
$-0.5 \%$
$4.7 \%$

SITC 4 - Animal and vegetable oils, fats and waxes
$0.2 \%$
$0.8 \%$
$-0.5 \%$
$21.5 \%$

SITC 5 - Chemicals and related products

$\begin{array}{llll}0.6 \% & 1.8 \% & 1.3 \% & 12.9 \%\end{array}$

SITC 6 - Manufactured goods

$$
\begin{array}{llll}
-0.8 \% & -0.5 \% & -0.2 \% & 17.9 \%
\end{array}
$$

SITC 7 - Machinery and Transport Equipment

$$
\begin{array}{llll}
5.5 \% & 9.5 \% & 21.6 \% & 28.5 \%
\end{array}
$$

SITC 8 - Miscellaneous manufactured articles

$$
\begin{array}{llll}
1.6 \% & 8.2 \% & 16.5 \% & 29.6 \%
\end{array}
$$

SITC 9 - Special commodities and transactions
$-2.1 \%$
$0.1 \%$
$-10.7 \%$
$14.1 \%$

$\begin{array}{lllll}\text { Total } & 1.4 \% & 4.1 & 4.2 \% & 16.7 \%\end{array}$

\section{Notes:}

Hong Kong markups are computed as described in Feenstra et al (1999). For the markups on goods inbound to China from Hong Kong, method A compares the Hong Kong import unit-value for each HS product to the unit-value for re-exports to China, whereas method B compares the import unit-value to the unit-value for all re-exports (of which about $80 \%$ on average go to China). Method C compares the import and export unit-values for 8-digit HS products only when the quantity of imports into Hong Kong are at least $90 \%$ of the quantity of re-exports to China. For the markups on goods outbound from China and re-exported through Hong Kong, method A compares the Hong Kong import unit-value to the unit-value of re-exports to each destination market. 


\section{References}

Aghion, Phillipe and Jean Tirole, 1997, "Formal and Real Authority in Organizations," Journal of Political Economy, 105(1), 1-29.

Anderson, Simon P., Andre de Palma, and Jacques-Francois Thisse. 1992. Discrete Choice Theory of Product Differentiation. Cambridge, MA: MIT Press.

Antras, Pol. 2002. "Firms, Contracts, and Trade Structure." Mimeo, MIT.

Baker, George P. and Thomas N. Hubbard. 2000a. "Contractibility and Asset Ownership: OnBoard Computers and Governance in U.S. Trucking.” NBER Working Paper No. 7634.

Baker, George P. and Thomas N. Hubbard. 2000b. "Make versus Buy in Trucking: Asset Ownership, Job Design, and Information.” Mimeo, Harvard University.

Baker, George P. and Thomas N. Hubbard. 2001. "Empirical Strategies in Contract Economics: Information and the Boundary of the Firm." American Economic Review 91(2), May, 189194.

Chen, Hongyi. 2000. The Institutional Transition of China's Township and Village Enterprises. Brookfield, VT: Ashgate.

Chiu, Stephen W.K., K.C. Ho, and Tai-Lok Lui. 1997. City-States and the Global Economy: Industrial Restructuring in Hong Kong and Singapore. Boulder, CO: Westview Press.

Demurger, Sylvie, Jeffrey D. Sachs, Wing Thye Woo, Shuming Bao, Gene Chang, and Andrew Mellinger. 2001. "Geography, Economic Policy, and Regional Development in China." Asian Economic Papers, forthcoming.

Ethier, Wilfred J. and James R. Markusen. 1996. "Multinational Firms, Technology Diffusion, and Trade." Journal of International Economics, 41(1): 1-28.

Feenstra, Robert C., Wen Hai, Wing T. Woo, and Shunli Yao. 1999. "Discrepancies in International Data: An Application to China-Hong Kong Entrepôt Trade," American Economic Review, May, 338-343.

Feenstra, Robert C. and Gordon H. Hanson. 2002. "Intermediaries in Entrepôt Trade: Hong Kong Re-Exports of Chinese Goods." Journal of Economics and Management Strategy, forthcoming.

Grossman, Sanford J. and Oliver D. Hart, 1986, "Costs and Benefits of Ownership: A Theory of Vertical and Lateral Integration," Journal of Political Economy, 94(3), August, 691-719. 
Groves, Theodore, Yongmiao Hong, John McMillan, and Barry Naughton. 1994. "Autonomy and Incentives in Chinese State Enterprises," Quarterly Journal of Economics, 109(1): 183-209.

Groves, Theodore, Yongmiao Hong, John McMillan, and Barry Naughton. 1995. "China's Evolving Managerial Labor Market," Journal of Political Economy, 103(3): 873-92.

Grossman, Gene and Elhanan Helpman. 2002a. "Integration versus Outsourcing in Industry Equilibrium." Quarterly Journal of Economics, 117(1), February, 85-120

Grossman, Gene and Elhanan Helpman. 2002b. "Outsourcing in a Global Economy." NBER Working Paper No. 8728.

Grossman, Gene and Elhanan Helpman. 2002c. "Managerial Incentives and the International Organization of Production." Mimeo, Princeton University and Tel Aviv University.

Hanson, Gordon H. 1995. "“"Incomplete Contracts, Risk, and Ownership," International Economic Review, 36: 341-63.

Hart, Oliver D. and John Moore, 1990, "Property Rights and the Nature of the Firm," Journal of Political Economy, 98, 1119-1158.

Hart, Oliver D. 1995. Firms, Contracts, and Financial Structure. Oxford: Oxford University Press.

Holmstrom, Bengt and Paul Milgrom, 1994, “The Firm as an Incentive System," American Economic Review, 84(3), 972-991.

Ke, Rongzhu and Weiying Zhang. undated. "Trust in China: A Cross-regional Analysis," Guanghua School of Management and Institute of Business Research, Peking University

Lin, Chu-Chia and Ivan Png. 2001. "Monitoring Costs and the Mode of International Investment." Mimeo, National University of Singapore.

Marin, Dalia and Thierry Verdier. 2001. "Power Inside the Firm and the Market: A General Equilibrium Approach.” Mimeo, University of Munich and DELTA.

Marin, Dalia and Thierry Verdier. 2003. "Globalization and the Empowerment of Human Capital." Mimeo, University of Munich and DELTA.

Markusen, James R. 2002. Multinational Firms and the Theory of International Trade. Cambridge, MA: MIT Press. 
Markusen, James R. and Keith E. Maskus. 2003. Discriminating among Alternative Theories of the Multinational Enterprise. In James Harrigan and Kwan Choi, editors, Handbook of International Trade, Basel Blackwell, forthcoming.

McLaren, John. 2000. “Globalization and Vertical Structure.” American Economic Review, 90(5): 1239-1254.

Naughton, Barry, 1996, “China's Emergence and Prospects as a Trading Nation,” Brookings Papers on Economic Activity, 2: 1996, pp. 273-343.

Naughton, Barry. 1997. The China Circle. Washington, DC: Brookings Institution Press.

Puga, Diego and Daniel Trefler. 2002. "Knowledge Creation and Control in Organizations." Mimeo, University of Toronto.

Rauch, James E., "Networks versus Markets in International Trade,” Journal of International Economics, 48(1), June 1999, 7-37.

Rauch, James E. and Alessandra Casella, 2003, “Overcoming Informational Barriers to International Resource Allocation: Prices and Group Ties," Economic Journal, forthcoming.

Sung, Yun-Wing. 1991. The China-Hong Kong Connection. Cambridge: Cambridge University Press.

Sung, Yun-Wing. 1998. Hong Kong and South China: The Economic Synergy. Hong Kong: City University of Hong Kong Press.

Tirole, Jean. 1999. “Incomplete Contracts: Where Do We Stand?” Econometrica 67(3), July, 741-781.

Train, Kenneth, 1986, Qualitative Choice Analysis. Cambridge: MIT Press.

Wang, Kui Hua. 2000. Chinese Commercial Law. Oxford: Oxford University Press.

Whinston, Michael 2001. “Assessing the Property-Rights and Transaction Cost Theories of Firm Scope." American Economic Review 91(2), May, 184-188.

World Bank. 1994. “China: Foreign Trade Reform.” Washington, DC.

Yeats, Alexander J. 2001. "Just How Big is Global Production Sharing?” in Sven W. Arndt and Henryk Kierzkowski (eds.), Fragmentation: New Production Patterns in the World Economy, Oxford: Oxford University Press. 
Table 1: Foreign Ownership, Export Processing, and Trade in China

\begin{tabular}{|c|c|c|c|c|c|}
\hline \multirow[b]{2}{*}{ Year } & \multirow{2}{*}{$\begin{array}{c}\text { Processing } \\
\text { Exports/ } \\
\text { Total } \\
\text { Exports } \\
\end{array}$} & \multirow{2}{*}{$\begin{array}{c}\text { FIE } \\
\text { Exports/ } \\
\text { Total } \\
\text { Exports }\end{array}$} & \multicolumn{3}{|c|}{ Share in Total Processing Exports of } \\
\hline & & & $\begin{array}{c}\text { Import-and- } \\
\text { Assembly }\end{array}$ & $\begin{array}{l}\text { Hong Kong } \\
\text { Re-Exports }\end{array}$ & FIE Exports \\
\hline 1997 & 0.545 & 0.361 & 0.704 & 0.556 & 0.561 \\
\hline 1998 & 0.568 & 0.393 & 0.705 & 0.552 & 0.587 \\
\hline 1999 & 0.568 & 0.413 & 0.677 & 0.507 & 0.609 \\
\hline 2000 & 0.552 & 0.439 & 0.701 & 0.470 & 0.646 \\
\hline 2001 & 0.554 & 0.462 & 0.714 & 0.456 & 0.669 \\
\hline 2002 & 0.550 & 0.484 & 0.741 & 0.436 & 0.697 \\
\hline
\end{tabular}

Notes: Columns (1) and (2) show processing exports and exports by foreign-invested enterprises, respectively, as a share of total China exports; columns (3)-(6) show as a share of total China processing exports, processing exports under the import-and-assembly regime, processing exports re-exported through Hong Kong, and processing exports by foreign-invested enterprises, respectively. 
Table 2: Optimal Effort Levels

\section{Ownership of the Factory}

$\delta_{2}=0$, Foreign firm f owns $\delta_{2}=1$, Chinese Manager g owns

$\delta_{1}=\mathbf{0}$,

Foreign firm

\begin{tabular}{|c|c|}
\hline $\mathrm{e}_{1}=\mathrm{P} / \gamma_{\mathrm{f}} \quad$ (first-best for $\left.\mathrm{f}\right)$ & $\mathrm{e}_{1}=[1-\phi(1-\theta) \psi] \mathrm{P} / \gamma_{\mathrm{f}}$ \\
$\mathrm{e}_{2}=(1-\phi \theta)(\mathrm{A}+\lambda \mathrm{B}) / \gamma_{\mathrm{g}}$ & $\mathrm{e}_{2}=[\mathrm{A}+(1-\phi \theta) \lambda \mathrm{B}] / \gamma_{\mathrm{g}}$ \\
$\mathrm{e}_{3}=\mathrm{B} / \gamma_{\mathrm{f}} \quad$ (first-best) & $\mathrm{e}_{3}=[1-\phi(1-\theta) \psi] \mathrm{B} / \gamma_{\mathrm{f}}$ \\
$\mathrm{W}(0,0)><\mathrm{W}(1,0)$ & $\mathrm{W}(0,1)<\mathrm{W}(1,1)$ if $\gamma_{\mathrm{f}}=\gamma_{\mathrm{g}}$ \\
$\mathrm{e}_{1}=(1-\phi \psi \theta) \mathrm{P} / \gamma_{\mathrm{g}}$ & $\mathrm{e}_{1}=\mathrm{P} / \gamma_{\mathrm{g}} \quad($ first-best for $\mathrm{g})$ \\
$\mathrm{e}_{2}=(1-\phi \psi \theta)(\mathrm{A}+\lambda \mathrm{B}) / \gamma_{\mathrm{g}}$ & $\mathrm{e}_{2}=[\mathrm{A}+(1-\phi \theta) \lambda \mathrm{B}] / \gamma_{\mathrm{g}}$ \\
$\mathrm{e}_{3}=\mathrm{B} / \gamma_{\mathrm{f}} \quad($ first-best $)$ & $\mathrm{e}_{3}=[1-\phi(1-\theta) \psi] \mathrm{B} / \gamma_{\mathrm{f}}$ \\
$\mathrm{W}(1,0)$ & $\mathrm{W}(1,1)$ \\
\hline
\end{tabular}

f controls inputs

Control

of the

Inputs

$\delta_{1}=1$,

Chinese manager g controls inputs 
Table 3: Processing Exports by Input Control and Factory Ownership Regime

\begin{tabular}{|c|c|c|c|c|}
\hline \multirow{4}{*}{ Control over Inputs: } & \multicolumn{2}{|c|}{ All Provinces } & \multicolumn{2}{|c|}{ Interior Provinces } \\
\hline & \multicolumn{2}{|c|}{ Ownership of Factory: } & \multicolumn{2}{|c|}{ Ownership of Factory. } \\
\hline & Foreign & Chinese & Foreign & Chinese \\
\hline & $\mathrm{S}(0,0)$ & $\mathrm{S}(0,1)$ & $\mathrm{S}(0,0)$ & $S(0,1)$ \\
\hline \multirow[t]{2}{*}{$\begin{array}{l}\text { Foreign Buyer } \\
\text { (pure-assembly) }\end{array}$} & $\begin{array}{c}0.083 \\
(0.001)\end{array}$ & $\begin{array}{c}0.271 \\
(0.003)\end{array}$ & $\begin{array}{c}0.177 \\
(0.007)\end{array}$ & $\begin{array}{c}0.110 \\
(0.004)\end{array}$ \\
\hline & $\mathrm{S}(1,0)$ & $\mathrm{S}(1,1)$ & $\mathrm{S}(1,0)$ & $\mathrm{S}(1,1)$ \\
\hline $\begin{array}{c}\text { Chinese Factory } \\
\text { (import-and-assembly) }\end{array}$ & $\begin{array}{c}0.496 \\
(0.003)\end{array}$ & $\begin{array}{c}0.146 \\
(0.002)\end{array}$ & $\begin{array}{c}0.416 \\
(0.011)\end{array}$ & $\begin{array}{c}0.297 \\
(0.009)\end{array}$ \\
\hline $\begin{array}{c}{[\ln S(0,0)+\ln S(1,1)]-} \\
{[\ln S(1,0)+\ln S(0,1)]}\end{array}$ & \multicolumn{2}{|c|}{$\begin{array}{l}-2.417 \\
(0.026)\end{array}$} & \multicolumn{2}{|c|}{$\begin{array}{c}0.141 \\
(0.064)\end{array}$} \\
\hline
\end{tabular}

Notes: This table shows means for shares of processing exports by factory ownership (foreign versus Chinese) and input-control regime (pure-assembly versus import-and-assembly) for observations by year, industry, destination country, origin province, and trade zone status. The first two columns show results for all provinces; the second two columns show results for interior provinces (all provinces excluding the southern coastal provinces of Shanghai, Zhejiang, Fujian, Guangdong, Hainan). Standard errors for the modularity measure (in parentheses) are obtained by bootstrapping with 100 replications. 
Table 4: Processing Exports depending on Trade Zone Status

\begin{tabular}{|c|c|c|c|c|}
\hline \multirow{4}{*}{ Control over Inputs: } & \multicolumn{2}{|c|}{ Inside SEZs } & \multicolumn{2}{|c|}{ Outside SEZs } \\
\hline & \multicolumn{2}{|c|}{ Ownership of Factory: } & \multicolumn{2}{|c|}{ Ownership of Factory: } \\
\hline & Foreign & Chinese & Foreign & Chinese \\
\hline & $\mathrm{S}(0,0)$ & $\mathrm{S}(0,1)$ & $\mathrm{S}(0,0)$ & $\mathrm{S}(0,1)$ \\
\hline \multirow[t]{2}{*}{$\begin{array}{l}\text { Foreign Buyer } \\
\text { (pure-assembly) }\end{array}$} & $\begin{array}{c}0.081 \\
(0.004)\end{array}$ & $\begin{array}{c}0.076 \\
(0.002)\end{array}$ & $\begin{array}{c}0.084 \\
(0.001)\end{array}$ & $\begin{array}{c}0.317 \\
(0.003)\end{array}$ \\
\hline & $\mathrm{S}(1,0)$ & $\mathrm{S}(1,1)$ & $\mathrm{S}(1,0)$ & $\mathrm{S}(1,1)$ \\
\hline $\begin{array}{l}\text { Chinese Factory } \\
\text { (import-and-assembly) }\end{array}$ & $\begin{array}{c}0.745 \\
(0.006)\end{array}$ & $\begin{array}{c}0.098 \\
(0.003)\end{array}$ & $\begin{array}{c}0.442 \\
(0.003)\end{array}$ & $\begin{array}{c}0.157 \\
(0.002)\end{array}$ \\
\hline $\begin{array}{c}{[\ln S(0,0)+\ln S(1,1)]-} \\
{[\ln S(1,0)+\ln S(0,1)]}\end{array}$ & \multicolumn{2}{|c|}{$\begin{array}{l}-1.967 \\
(0.069)\end{array}$} & \multicolumn{2}{|c|}{$\begin{array}{l}-2.367 \\
(0.025)\end{array}$} \\
\hline
\end{tabular}

Notes: This table shows mean shares of processing exports by factory ownership and inputcontrol regime for goods produced inside (columns 1 and 2) and outside (columns 3 and 4) of Special Economic Zones. See also notes to Table 3.

Table 5: Processing Exports by depending on Export Route

\begin{tabular}{|c|c|c|c|c|}
\hline \multirow{4}{*}{ Control over Inputs: } & \multicolumn{2}{|c|}{ Hong Kong Re-Exports } & \multicolumn{2}{|c|}{ Direct Exports } \\
\hline & \multicolumn{2}{|c|}{ Ownership of Factory: } & \multicolumn{2}{|c|}{ Ownership of Factory: } \\
\hline & Foreign & Chinese & Foreign & Chinese \\
\hline & $\mathrm{S}(0,0)$ & $\mathrm{S}(0,1)$ & $\mathrm{S}(0,0)$ & $\mathrm{S}(0,1)$ \\
\hline \multirow[t]{2}{*}{$\begin{array}{l}\text { Foreign Buyer } \\
\text { (pure-assembly) }\end{array}$} & $\begin{array}{c}0.024 \\
(0.001)\end{array}$ & $\begin{array}{c}0.367 \\
(0.004)\end{array}$ & $\begin{array}{c}0.160 \\
(0.003)\end{array}$ & $\begin{array}{c}0.154 \\
(0.003)\end{array}$ \\
\hline & $\mathrm{S}(1,0)$ & $\mathrm{S}(1,1)$ & $\mathrm{S}(1,0)$ & $\mathrm{S}(1,1)$ \\
\hline $\begin{array}{c}\text { Chinese Factory } \\
\text { (import-and-assembly) }\end{array}$ & $\begin{array}{c}0.490 \\
(0.004)\end{array}$ & $\begin{array}{c}0.119 \\
(0.002)\end{array}$ & $\begin{array}{c}0.504 \\
(0.005)\end{array}$ & $\begin{array}{c}0.182 \\
(0.003)\end{array}$ \\
\hline $\begin{array}{c}{[\ln S(0,0)+\ln S(1,1)]-} \\
{[\ln S(1,0)+\ln S(0,1)]}\end{array}$ & \multicolumn{2}{|c|}{$\begin{array}{r}-4.142 \\
(0.040)\end{array}$} & \multicolumn{2}{|c|}{$\begin{array}{l}-0.984 \\
(0.031)\end{array}$} \\
\hline
\end{tabular}

Notes: This table shows mean shares of processing exports by factory ownership and inputcontrol regime for goods shipped directly to destination markets (columns 1 and 2) and goods reexported through Hong Kong (columns 3 and 4). See also notes to Table 3. 
Table 6: Processing Exports for Low Value-Added Industries

\begin{tabular}{|c|c|c|c|c|}
\hline \multirow{4}{*}{ Control over Inputs: } & \multicolumn{2}{|c|}{ Apparel } & \multicolumn{2}{|c|}{ Footwear } \\
\hline & \multicolumn{2}{|c|}{ Ownership of Factory: } & \multicolumn{2}{|c|}{ Ownership of Factory: } \\
\hline & Foreign & Chinese & Foreign & Chinese \\
\hline & $\mathrm{S}(0,0)$ & $\mathrm{S}(0,1)$ & $\mathrm{S}(0,0)$ & $S(0,1)$ \\
\hline \multirow[t]{2}{*}{$\begin{array}{l}\text { Foreign Buyer } \\
\text { (pure-assembly) }\end{array}$} & $\begin{array}{c}0.225 \\
(0.003)\end{array}$ & $\begin{array}{c}0.286 \\
(0.003)\end{array}$ & $\begin{array}{c}0.104 \\
(0.007)\end{array}$ & $\begin{array}{c}0.178 \\
(0.007)\end{array}$ \\
\hline & $\mathrm{S}(1,0)$ & $\mathrm{S}(1,1)$ & $\mathrm{S}(1,0)$ & $S(1,1)$ \\
\hline $\begin{array}{c}\text { Chinese Factory } \\
\text { (import-and-assembly) }\end{array}$ & $\begin{array}{c}0.302 \\
(0.003)\end{array}$ & $\begin{array}{c}0.187 \\
(0.002)\end{array}$ & $\begin{array}{c}0.579 \\
(0.009)\end{array}$ & $\begin{array}{c}0.140 \\
(0.003)\end{array}$ \\
\hline $\begin{array}{c}{[\ln S(0,0)+\ln S(1,1)]-} \\
{[\ln S(1,0)+\ln S(0,1)]}\end{array}$ & & & & \\
\hline
\end{tabular}

Notes: This table shows mean shares of processing exports by factory ownership and inputcontrol regime for Apparel (SITC 84, columns 1 and 2) and Footwear (SITC 85, columns 3 and 4). See also notes to Table 3.

Table 7: Processing Exports for High Value-Added Industries

\begin{tabular}{|c|c|c|c|c|}
\hline \multirow{4}{*}{ Control over Inputs: } & \multicolumn{2}{|c|}{ Office Machines } & \multicolumn{2}{|c|}{ Electrical Machinery } \\
\hline & \multicolumn{2}{|c|}{ Ownership of Factory: } & \multicolumn{2}{|c|}{ Ownership of Factory: } \\
\hline & Foreign & Chinese & Foreign & Chinese \\
\hline & $\mathrm{S}(0,0)$ & $\mathrm{S}(0,1)$ & $\mathrm{S}(0,0)$ & $S(0,1)$ \\
\hline \multirow[t]{2}{*}{$\begin{array}{l}\text { Foreign Buyer } \\
\text { (pure-assembly) }\end{array}$} & $\begin{array}{c}0.033 \\
(0.006)\end{array}$ & $\begin{array}{c}0.211 \\
(0.013)\end{array}$ & $\begin{array}{c}0.070 \\
(0.006)\end{array}$ & $\begin{array}{c}0.246 \\
(0.005)\end{array}$ \\
\hline & $\mathrm{S}(1,0)$ & $\mathrm{S}(1,1)$ & $S(1,0)$ & $\mathrm{S}(1,1)$ \\
\hline $\begin{array}{c}\text { Chinese Factory } \\
\text { (import-and-assembly) }\end{array}$ & $\begin{array}{c}0.693 \\
(0.016)\end{array}$ & $\begin{array}{c}0.062 \\
(0.008)\end{array}$ & $\begin{array}{c}0.575 \\
(0.007)\end{array}$ & $\begin{array}{c}0.109 \\
(0.004)\end{array}$ \\
\hline $\begin{array}{c}{[\ln S(0,0)+\ln S(1,1)]-} \\
{[\ln S(1,0)+\ln S(0,1)]}\end{array}$ & \multicolumn{2}{|c|}{$\begin{array}{l}-4.265 \\
(0.223)\end{array}$} & \multicolumn{2}{|c|}{$\begin{array}{l}-2.925 \\
(0.106)\end{array}$} \\
\hline
\end{tabular}

Notes: This table shows mean shares of processing exports by factory ownership and inputcontrol regime for Office Machines (SITC 75, columns 1 and 2) and Electrical Machinery (SITC 77, columns 3 and 4). See also notes to Table 3. 
Table 8: MNL Estimates of the Property Rights Model

\begin{tabular}{|c|c|c|c|c|c|c|}
\hline & \multicolumn{2}{|c|}{ Equation (17a) } & \multicolumn{2}{|c|}{ Equation (17b) } & \multicolumn{2}{|c|}{ Equation (17b) } \\
\hline $\begin{array}{c}\text { Intercept } \\
(\text { Year = 2002) }\end{array}$ & \multicolumn{2}{|c|}{$\begin{array}{c}0.74 \\
(0.15)\end{array}$} & \multicolumn{2}{|c|}{$\begin{array}{l}-0.47 \\
(0.16)\end{array}$} & \multicolumn{2}{|c|}{$\begin{array}{l}1.24 \\
(0.14)\end{array}$} \\
\hline $\begin{array}{c}\text { Inbound } \\
\text { value-added ratio }\end{array}$ & \multicolumn{2}{|c|}{$\begin{array}{c}-0.34 \\
(0.054)\end{array}$} & \multicolumn{2}{|c|}{$\begin{array}{l}-0.036 \\
(0.072)\end{array}$} & \multicolumn{2}{|c|}{$\begin{array}{c}-0.17 \\
(0.050)\end{array}$} \\
\hline $\begin{array}{c}\text { Outbound } \\
\text { value-added ratio }\end{array}$ & \multicolumn{2}{|c|}{$\begin{array}{l}-0.007 \\
(0.014)\end{array}$} & \multicolumn{2}{|c|}{$\begin{array}{c}0.013 \\
(0.021)\end{array}$} & \multicolumn{2}{|c|}{$\begin{array}{c}0.035 \\
(0.017)\end{array}$} \\
\hline Years: & 1997-99 & $2000-02$ & 1997-99 & 2000-02 & 1997-99 & 2000-02 \\
\hline Hong-Kong & $\begin{array}{l}-0.061 \\
(0.20)\end{array}$ & $\begin{array}{c}0.24 \\
(0.15)\end{array}$ & $\begin{array}{c}0.16 \\
(0.23)\end{array}$ & $\begin{array}{c}0.59 \\
(0.16)\end{array}$ & $\begin{array}{l}0.001 \\
(0.22)\end{array}$ & $\begin{array}{c}0.26 \\
(0.16)\end{array}$ \\
\hline SEZ & $\begin{array}{l}-0.21 \\
(0.15)\end{array}$ & $\begin{array}{c}0.47 \\
(0.11)\end{array}$ & $\begin{array}{c}0.19 \\
(0.31)\end{array}$ & $\begin{array}{l}-0.90 \\
(0.20)\end{array}$ & $\begin{array}{c}0.12 \\
(0.24)\end{array}$ & $\begin{array}{l}-0.48 \\
(0.16)\end{array}$ \\
\hline North coast & $\begin{array}{c}0.32 \\
(0.21)\end{array}$ & $\begin{array}{l}-0.18 \\
(0.16)\end{array}$ & $\begin{array}{l}-0.25 \\
(0.24)\end{array}$ & $\begin{array}{l}-0.018 \\
(0.15)\end{array}$ & $\begin{array}{c}0.54 \\
(0.24)\end{array}$ & $\begin{array}{l}-1.53 \\
(0.18)\end{array}$ \\
\hline Beijing area & $\begin{array}{c}0.11 \\
(0.20)\end{array}$ & $\begin{array}{l}-0.21 \\
(0.15)\end{array}$ & $\begin{array}{l}-0.12 \\
(0.20)\end{array}$ & $\begin{array}{l}-0.040 \\
(0.12)\end{array}$ & $\begin{array}{c}0.32 \\
(0.22)\end{array}$ & $\begin{array}{l}-1.18 \\
(0.16)\end{array}$ \\
\hline Shanghai area & $\begin{array}{l}-0.14 \\
(0.19)\end{array}$ & $\begin{array}{c}0.57 \\
(0.14)\end{array}$ & $\begin{array}{l}-0.56 \\
(0.22)\end{array}$ & $\begin{array}{c}0.72 \\
(0.12)\end{array}$ & $\begin{array}{l}0.027 \\
(0.20)\end{array}$ & $\begin{array}{l}-0.48 \\
(0.14)\end{array}$ \\
\hline South coast & $\begin{array}{c}0.75 \\
(0.29)\end{array}$ & $\begin{array}{c}1.94 \\
(0.20)\end{array}$ & $\begin{array}{c}0.25 \\
(0.37)\end{array}$ & $\begin{array}{c}2.42 \\
(0.24)\end{array}$ & $\begin{array}{c}1.10 \\
(0.30)\end{array}$ & $\begin{array}{l}-0.14 \\
(0.21)\end{array}$ \\
\hline
\end{tabular}

Notes: $\mathrm{N}=1,118,883$, across 8 -digit harmonized system (HS) products, provinces, years, and destination markets. The inbound (outbound) value-added ratio equal the markup on Hong Kong re-exports entering (leaving) China, divided by the value-added in processing trade within China. These ratios are measured at the 1-digit SITC industry rather than 8-digit HS product, so the standard errors (in parentheses) are corrected for correlation of errors across observations. The variable SEZ equals one if the HS products are produced in a Special Economic Zone (including high-technology development zones), and HongKong equals one if the good is re-exported through Hong Kong. All regressions include indicator variables for the year (with 2002 excluded). The northern coast consists of Heilongjiang, Jilin and Lioning; the area around Beijing includes Beijing/Tianjin, Hebei and Shandong; the area around Shanghai includes Shanghai, Jiangsu and Zhejing; and the southern coastal provinces consist of Fujian, Guangdong, and Hainan Island. 
Table 9: Parameter Estimates

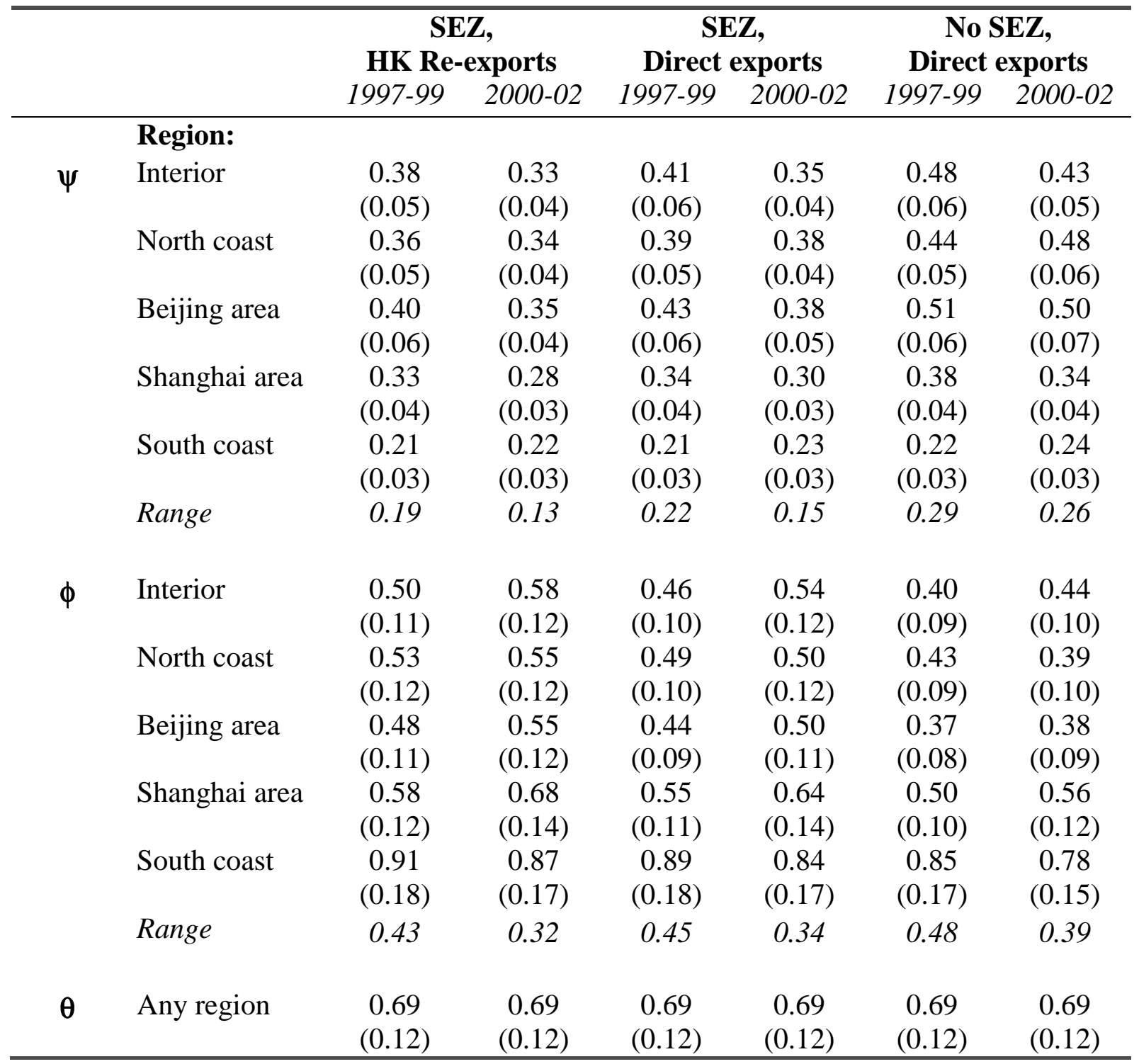

Notes: Parameters estimates are calculated from the coefficients in Table 8 and equations (17). The parameter $\psi$ is the degree of human-capital specificity, $\phi$ is the probability that contracts cannot be enforced so that Nash bargaining is used, and $\theta$ is bargaining weight of the foreign firm. Standard errors are obtained by bootstrapping (17) using 100 replications. The range indicates the difference between the maximum and minimum estimates across regions. 
Table 10: Alternative Parameter Estimates, 2000-02

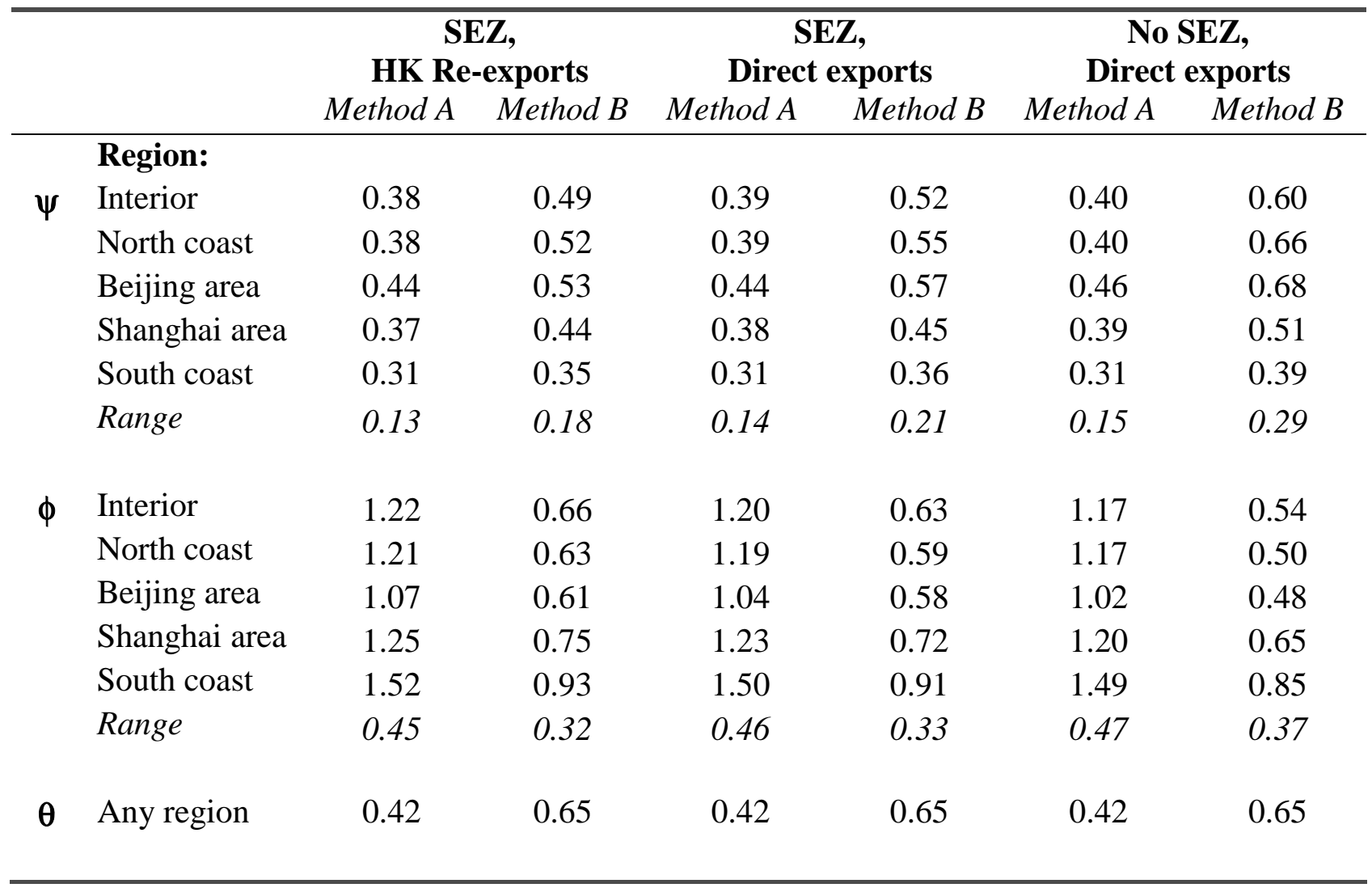

Notes: Alternative parameters estimates are calculated by changing the method of computing the Hong Kong markups, used to construct the inbound and outbound value-added ratios. Tables 8 and 9 use method $\mathrm{C}$ to calculate the markups, whereas the above estimates use methods $\mathrm{A}$ and B. See Feenstra et al (1999) and the data appendix for more information on these methods for computing markups, and see the notes to Table 9 for parameter definitions. 